\title{
34. LONG-TERM CHANGES IN THE ACCUMULATION OF ORGANIC CARBON IN NEOGENE SEDIMENTS, ONTONG JAVA PLATEAU ${ }^{1}$
}

\author{
Rainer Stax ${ }^{2}$ and Ruediger Stein ${ }^{2}$
}

\begin{abstract}
Organic geochemical investigations were performed on sediments of Leg 130 to reconstruct the depositional environment of the Ontong Java Plateau. The Miocene to Quaternary sediments collected during the drilling campaign are characterized by extremely low organic carbon contents. As indicated by $\mathrm{C} / \mathrm{N}$ ratios and Rock-Eval data, most of the organic matter is probably of marine origin. Based on mass-accumulation rates of organic carbon, the paleoproductivity for the Miocene-Pliocene and the late Pliocene-Pleistocene time intervals as well as the modem surface-water production were estimated. The productivity values of the surface sediments (25-59 $\mathrm{gC} / \mathrm{m}^{2} / \mathrm{yr}$ ) reflect the various influences of the equatorial upwelling cell on the different sites. The accumulation rates of organic carbon are generally low; however, they show a distinct increase at $8 \mathrm{Ma}$ and a decrease at $2 \mathrm{Ma}$.
\end{abstract}

\section{INTRODUCTION}

The Ontong Java Plateau, the world's largest mid-oceanic submarine plateau, extends across an area of about $1000 \cdot 1500 \mathrm{~km}^{2}$ in the western equatorial Pacific. It rises from the deep seafloor at about 4500 to $1700 \mathrm{~m}$ below the surface on top of the plateau. The volcanic plateau built up rapidly in about 3.5 m.y. (Tarduno et al., this volume), probably 113 m.y. ago, and moved northward to the equator. During this journey the plateau accumulated a more than 1000 -m-thick pelagic sediment column, which has been the subject of several previous expeditions (Winterer, Riedel, et al., 1971; Andrews, Packham, et al., 1975; Moberly, Schlanger, et al., 1986).

Ocean Drilling Program (ODP) Leg 130 drilled Sites 803 through 807 (Kroenke, Berger, Janecek, et al., 1991; Fig. 1 and Table 1) at various depths on a transect over the Ontong Java Plateau. The main objectives were to recover complete and undisturbed sediment records of Neogene, Paleogene, and Late Cretaceous time that would provide the unique possibility to acquire important information about the paleoceanography and paleoclimate of the western Pacific region.

The depositional sequence covering the Ontong Java Plateau is well suited for detailed reconstructions of the carbonate dissolution and mass-wasting history (Berger and Johnson, 1976) and the diagenetic influence on sediments at different water depths. Furthermore, because of the elevated position of the plateau, its sediments are sensitive to global paleoceanographic events, which possibly can be correlated with seismic reflectors (Mayer et al., 1986). Sites 803, 804,805 , and 806 were drilled in a transect across the northeastern flank of the plateau to collect a series of sediment records from water depths ranging between 2500 and $3900 \mathrm{~m}$, whereas Site 807 was located on top of the plateau in a water depth of $2805 \mathrm{~m}$ (Fig. 1). At Sites 803 and 807 , drilling penetrated through the sediment column into basement.

The purpose of this study is to investigate the amount of preserved organic carbon in the Leg 130 sediments. Based on these measurements, modern surface-water productivity as well as late Cenozoic productivity are estimated from sediment data and compared with data from the literature.

\footnotetext{
${ }^{1}$ Berger, W.H., Kroenke, L.W., Mayer, L.A., et al., 1993. Proc. ODP, Sci. Results, 130: College Station, TX (Ocean Drilling Program).

${ }^{2}$ Alfred-Wegener Institute for Polar and Marine Research, Columbusstrasse, D-2850 Bremerhaven, Federal Republic of Germany.
}

\section{METHODS}

The samples used for this study were taken on board JOIDES Resolution during Leg 130 using a $10-\mathrm{cm}^{3}$ sampling cylinder. Determination of the total organic carbon (TOC) content of the samples required two measurements of a HERAEUS CHN Analyzer. Total carbon was measured from dried and ground bulk sediment samples (see Appendix), and the organic carbon of carbonate free samples was measured on split samples treated with $10 \% \mathrm{HCl}$, washed and dried. The organic carbon content (wt\%) of the bulk sediment was then calculated using the following equation:

$$
\text { TOC }=\frac{100-(8.334 \cdot \mathrm{TC})}{\left(100 / \mathrm{TOC}^{\prime}\right)-8.334},
$$

in which TC is the total carbon of the bulk sample and TOC' is the organic carbon of the carbonate-free residue. Total nitrogen measurements were also performed with the CHN Analyzer. The accuracy of the HERAEUS CHN Analyzer is $0.02 \%$.

Seven samples of Hole 806B were analyzed in a DELSI, Inc., Rock-Eval II instrument (Espitalié et al., 1977). According to standard procedures as described in Emeis and Kvenvolden (1986), approximately $100 \mathrm{mg}$ of the carbonate-free residue of selected samples $\left(\right.$ TOC $^{\prime}>1.5 \%$ ) were measured (Table 2 ).

Mass accumulation rates (MAR) were calculated according to Van Andel et al. (1975) with physical properties and sedimentation rate data from Kroenke, Berger, Janecek, et al. (1991):

$$
\mathrm{MAR}_{\mathrm{TOC}}=(\mathrm{TOC} / 100) \mathrm{LSR}[\mathrm{WBD}-1.026(\mathrm{PO} / 100)],
$$

in which MAR = mass accumulation rate $\left(\mathrm{g} / \mathrm{m}^{2} / \mathrm{yr}\right) ;$ TOC $=$ total organic carbon $(w t \%)$; LSR = linear sedimentation rates $(\mathrm{m} / \mathrm{m}$.y.); $\mathrm{WBD}=$ wet-bulk density $\left(\mathrm{g} / \mathrm{cm}^{3}\right) ;$ and $\mathrm{PO}=$ porosity $(\%)$.

The surface-water paleoproductivity was estimated using the following equation:

$$
\mathrm{PP}=5.31[\mathrm{C}(\mathrm{WBD}-1.026 \mathrm{PO} / 100)]^{0.71} \mathrm{LSR}^{0.07} \mathrm{DEP}^{0.45},
$$

in which $\mathrm{PP}=$ primary production $\left(\mathrm{gC} / \mathrm{m}^{2} / \mathrm{yr}\right), \mathrm{C}=$ (marine) organic carbon $(w t \%), \mathrm{WBD}=$ wet-bulk density $\left(\mathrm{g} / \mathrm{cm}^{3}\right), \mathrm{PO}=$ porosity $(\%)$, $\mathrm{LSR}=$ linear sedimentation rate $(\mathrm{cm} / 1000 \mathrm{yr})$, and $\mathrm{DEP}=$ paleowater depth of the seafloor (m). This empirical formula is based on the relationships among organic carbon accumulation rates in surface sediments, sedimentation rates, water depths, and measured (recent) 


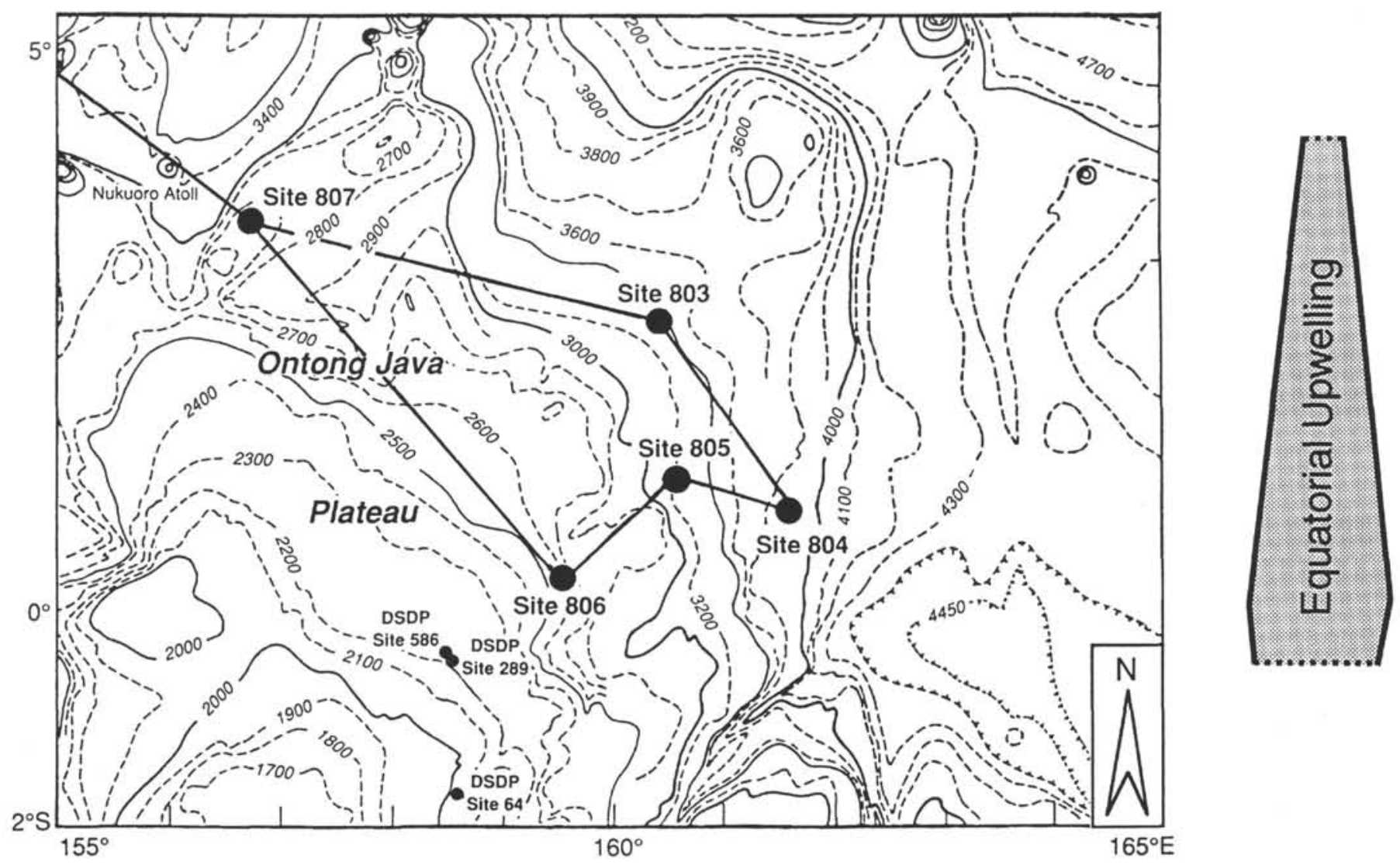

Figure 1. Location map of DSDP Sites 64, 289, and 586 and Leg 130 Sites 803 through 807 on the Ontong Java Plateau. Shaded area indicates the influence of equatorial upwelling.

Table 1. Site locations and water depths, Leg 130.

\begin{tabular}{cccc}
\hline Site & $\begin{array}{c}\text { Latitude } \\
(\mathrm{N})\end{array}$ & $\begin{array}{c}\text { Longitude } \\
(\mathrm{E})\end{array}$ & $\begin{array}{c}\text { Water } \\
\text { depth } \\
(\mathrm{m})\end{array}$ \\
\hline 803 & $2^{\circ} 25.98^{\prime}$ & $160^{\circ} 32.40^{\prime}$ & 3410 \\
804 & $1^{\circ} 00.28^{\prime}$ & $161^{\circ} 35.62^{\prime}$ & 3861 \\
805 & $1^{\circ} 13.68^{\prime}$ & $160^{\circ} 31.76^{\prime}$ & 3188 \\
806 & $0^{\circ} 19.11^{\prime}$ & $159^{\circ} 21.68^{\prime}$ & 2520 \\
807 & $3^{\circ} 36.42^{\prime}$ & $156^{\circ} 37.49^{\prime}$ & 2805 \\
\hline
\end{tabular}

surface-water productivity. The oxidation of organic matter within the water column and during burial into the sediment is also considered in the equation, which was developed for oxic environments (Stein, 1986b; based on Müller and Suess, 1979; Betzer et al., 1984).

Based on the fact that the Leg 130 sediments consist almost completely of marine biogenic skeletons (Kroenke, Berger, Janecek, et al., 1991) and the low $\mathrm{C} / \mathrm{N}$ ratios and relatively high hydrogen index values (see below), it is assumed that the organic matter is also mainly of marine origin. Thus, to estimate the paleoproductivity, the total organic carbon fraction was used as marine organic carbon in Equation 3.

\section{RESULTS}

The Neogene sediments recovered during Leg 130 are characterized by very low organic carbon contents throughout the entire sequence (below $0.3 \%$; Fig. 2). Such values, however, are similar to those recorded in other highly open-marine oxic environments (Romankevich, 1984; Stein et al., 1989). All five sites display a charac- teristic pattern in TOC content. Values of about $0.04 \%$ for sediments between 25 and $6 \mathrm{Ma}$ increase abruptly to $>0.1 \%$ in the interval from $6 \mathrm{Ma}$ to the Holocene.

Site 806 has the highest TOC contents of all the Leg 130 sites, with maximum values up to $0.3 \%$ and a variation of $0.2 \%$ in upper PliocenePleistocene sediments, whereas at Sites 803 and 807 most of the values do not exceed $0.1 \%$ TOC within sediments of this time interval (Fig. 2). Also, the amplitude of the fluctuation in TOC at Sites 803 and 807 is within $0.06 \%$ to $0.1 \%$ distinctly lower than at Site 806 . The TOC values of the interval from the last 6 m.y. vary at Site 804 between $0.05 \%$ and $0.15 \%$, and between $0.05 \%$ and $0.2 \%$ at Site 805 . A spike up to $0.3 \%$ occurs at about $1.8 \mathrm{Ma}$ in the Site 805 sediments (Fig. 2).

\section{Accumulation Rates}

The accumulation rates of organic carbon were calculated for the Leg 130 sites to interpret the data in terms of change in flux. In Figure 2 , the flux rates are shown as the average rates between stratigraphic datum levels used as absolute time constraints (from Kroenke, Berger, Janecek, et al., 1991). The records of Sites $803,805,806$ and 807 show a characteristic pattern with very low rates $\left(0.005-0.015 \mathrm{~g} / \mathrm{m}^{2} / \mathrm{yr}\right)$ for the lower and middle Miocene (25-8.7 Ma) and increasing values (maximum rates between $0.01 \mathrm{~g} / \mathrm{m}^{2} / \mathrm{yr}$ at Site 803 and $0.05 \mathrm{~g} / \mathrm{m}^{2} / \mathrm{yr}$ at Site 806) for the upper Miocene to Pliocene (8.7-2 Ma). The uppermost Pliocene-Pleistocene sediments (i.e., the last $2 \mathrm{~m}$.y.) display distinctly decreased accumulation rates (between $0.005 \mathrm{~g} / \mathrm{m}^{2} / \mathrm{yr}$ at Site 803 and $0.03 \mathrm{~g} / \mathrm{m}^{2} / \mathrm{yr}$ at Site 806). As a result of large-scale hiatuses and a possible drilling disturbance at Hole $804 \mathrm{C}$, the average flux rate record is unreliable and does not show the typical pattern of the other four sites (Fig. 2). The accumulation rates of organic carbon at Hole 804C vary between 0.003 and $0.01 \mathrm{~g} / \mathrm{m}^{2} / \mathrm{yr}$. 
Table 2. Results of Rock-Eval pyrolysis of sediments from Site 806.

\begin{tabular}{lrrrr}
\hline $\begin{array}{c}\text { Core, section, } \\
\text { interval (cm) }\end{array}$ & $\begin{array}{c}\text { Depth } \\
\text { (mbsf) }\end{array}$ & $\begin{array}{c}\text { Age } \\
(\mathrm{Ma})\end{array}$ & HI & OI \\
\hline 130-806B- & & & & \\
& & & & \\
6H-5, 121 & 51.71 & 2.24 & 186 & 142 \\
$9 \mathrm{H}-5,120$ & 80.20 & 3.11 & 184 & 128 \\
$12 \mathrm{H}-5,121$ & 108.71 & 3.85 & 158 & 134 \\
$19 \mathrm{H}-5,119$ & 175.19 & 5.28 & 159 & 122 \\
$24 \mathrm{H}-5,121$ & 222.71 & 6.30 & 159 & 112 \\
$25 \mathrm{H}-5,121$ & 232.21 & 6.50 & 156 & 117 \\
$42 \mathrm{X}-5,125$ & 395.15 & 10.77 & 259 & 133 \\
\hline
\end{tabular}

Note: $\mathrm{HI}=$ hydrogen index and $\mathrm{OI}=$ oxygen index .

\section{Organic Carbon/Nitrogen Ratios and Rock-Eval Pyrolysis}

Estimating the surface-water paleoproductivity from organic carbon content requires information about the composition of the organic matter (i.e., how much is of marine origin). Organic carbon/nitrogen $(\mathrm{C} / \mathrm{N})$ ratios might yield the first information about this composition. Marine planktonic organisms produce organic matter with characteristic mean $\mathrm{C} / \mathrm{N}$ ratios of about 6 (Bordowskiy, 1965a, 1965b; Scheffer and Schachtschabel, 1984). Higher C/N ratios of more than 15 point to a significant amount of organic material derived from land plants in the sediments.

In general, the influence of diagenesis on the preservation of the atomic $\mathrm{C} / \mathrm{N}$ ratio of organic matter in sediments is the subject of discussion in the literature (e.g., Macko and Pereira, 1990; Müller, 1977; Waples and Sloan, 1980). Assuming a related degradation of carbon and nitrogen at least back to $25 \mathrm{Ma}$ (Macko and Pereira, 1990), the $\mathrm{C} / \mathrm{N}$ ratios of the sediments probably reflect the primary $\mathrm{C} / \mathrm{N}$ ratio, although only a small amount of the organic fraction produced on the surface is preserved in the sediments.

In this study, the carbonate-free residue was used to determine the $\mathrm{C} / \mathrm{N}$ ratios (Fig. 3 and Appendix) because the nitrogen content of the bulk sample was not detectable in most cases. The organic carbon and nitrogen values of the carbonate-free samples vary between 0.1 and $2.71 \%$ and 0.01 and $0.3 \%$, respectively (Appendix). The $\mathrm{C} / \mathrm{N}$ ratios at Sites 803 through 807 vary between 3 and 10 (Fig. 3). At Site 806 , some higher ratios between 10 and 14 occur in the interval before $8 \mathrm{Ma}$, possibly indicating more terrigenous organic components in the sediments. In these organic-carbon-poor sediments, however, $\mathrm{C} / \mathrm{N}$ ratios have to be interpreted with caution as an indicator for the quality of organic material (e.g., Müller, 1977).

The results of the Rock-Eval analysis are presented as a diagram of hydrogen index ( $\mathrm{mgHC} / \mathrm{gTOC})$ vs. oxygen index $\left(\mathrm{mgCO}_{2} / \mathrm{gTOC}\right)$ (Fig. 4). In general, the $\mathrm{HI}$ and $\mathrm{OI}$ values vary between 156 and 260 $\mathrm{mgHC} / \mathrm{gTOC}$ and 112 and $142 \mathrm{mgCO}_{2} / \mathrm{gTOC}$, respectively (Table 2), indicating the presence of significant amounts of marine organic matter. The HI values, for example, are in the same range as those determined in late Cenozoic sediments from the upwelling area off northwest Africa, where most of the organic matter is of marine origin (e.g., Stein, 1991).

\section{DISCUSSION AND CONCLUSIONS}

The depositional regime on the Ontong Java Plateau can be characterized as an highly oxidizing environment influenced by equatorial upwelling (Fig. 1). The pelagic carbonate sediments of this region contain extremely fewer amounts of organic carbon compared with other marine deposits such as those of shallower water depth or coastal upwelling environments (Romankevich, 1984; Suess, 1980; Ten Haven et al., 1990).

The burial of organic carbon in the sediment column is the result of complex and only partly understood processes. In the euphotic zone
Table 3. Calculated values of surface-water productivity, "export production," carbon flux at the seafloor, and accumulation rates of marine organic carbon.

\begin{tabular}{|c|c|c|c|c|c|}
\hline Site & 803 & 804 & 805 & 806 & 807 \\
\hline $\begin{array}{l}{ }^{\text {SSurface-water }} \\
\text { productivity } \\
\left(\mathrm{gC} / \mathrm{m}^{2} / \mathrm{yr}\right)\end{array}$ & 25 & 43 & 45 & 59 & 46 \\
\hline $\begin{array}{l}{ }^{b} \text { Export production } \\
\left(\mathrm{gC} / \mathrm{m}^{2} / \mathrm{yr}\right)\end{array}$ & 1.6 & 4.4 & 4.7 & 8.0 & 5.0 \\
\hline Depth (m) & 3410 & 3861 & 3188 & 2520 & 2805 \\
\hline $\begin{array}{l}{ }^{b} \text { Carbon flux at } \\
\text { seafloor } \\
\left(\mathrm{gC} / \mathrm{m}^{2} / \mathrm{yr}\right)\end{array}$ & 0.2 & 0.5 & 0.5 & 0.9 & 0.6 \\
\hline $\begin{array}{l}\text { TOC MAR } \\
\qquad\left(\mathrm{gC} / \mathrm{m}^{2} / \mathrm{yr}\right)\end{array}$ & 0.005 & 0.01 & 0.02 & $0.03-0.04$ & 0.02 \\
\hline
\end{tabular}

a Calculated using Equation 3 (see text).

${ }^{\mathrm{b}}$ For calculation procedure, see Berger et al. (1989), Betzer et al. (1984), and Stein (1991).

of the ocean's surface, planktonic organisms produce organic material that sinks slowly. On the way through the euphotic zone, the organic matter is oxidized and/or recycled by other organisms. Only a small amount, the "new production" (Berger et al., 1989; Eppley, 1989; Stein, 1991; Table 3), leaves this zone and sinks to the seafloor. During its fall through a highly oxic water column, such as present on the Ontong Java Plateau, the organic carbon is subject to strong degradation that results in a significant reduction in the amount of organic material that reaches the seafloor (Suess, 1980; Betzer et al., 1984; Walsh, 1989; Table 3). Additional factors, such as sedimentation rate and bottom-water oxygen content, support the further decay of the organic material during the burial process. These various factors make it difficult to estimate the primary productivity from the organic carbon content of the sediment (Emerson, 1985; Emerson et al., 1985; Sarnthein et al., 1987; Stein, 1991).

The modern primary production for the five site positions of Leg 130 was estimated using the organic carbon content of the near-surface sample after Equation 3. The productivity values at Sites 803 through 807 (Table 3) corroborate quite well those given in the global productivity distribution maps of Berger (in press) and Koblents-Mishke et al. (1970) for this region. At Site 806, the highest productivity of $59 \mathrm{gC} / \mathrm{m}^{2} / \mathrm{yr}$ reflects that the position closest to the equator has the greatest influence from equatorial upwelling of all the Leg 130 sites. The lowest production rate of $25 \mathrm{gC} / \mathrm{m}^{2} / \mathrm{yr}$, which was calculated for the deep Site 803 on the northern flank of the Ontong Java Plateau, probably reflects the diminished influence of the upwelling cell as compared with the other sites (Fig. 1).

The TOC accumulation rates of the Leg 130 sediments are generally low (Fig. 2), but they show a distinct increase between 8 and 2 $\mathrm{Ma}$, which might reflect a long-term change in oceanic circulation and paleoproductivity. This variation is in the same range as the productivity pulses described by Pedersen et al. (1991) for the Quaternary glacial/interglacial cycles in the Panama Basin. The calculated productivity values (Eq. 3 ) do not show this long-term change. It has to be considered, however, that the quantification of paleoproductivity in the extremely organic-carbon-poor Miocene sediments from the Ontong Java Plateau using Equation 3 has to be seen with caution because these data points are close to the lower limit of use of the equation (cf. Fig. 5; Müller and Suess, 1979; Stein, 1986a). Figure 5 illustrates the correlation between sedimentation rate and organic carbon content in oxic environments, which is the basis for the deduction of Equation 3. The very low values of the Leg 130 sediments scatter in the low SR/low TOC field, indicating a generally low productivity (which seems to be meaningful). 

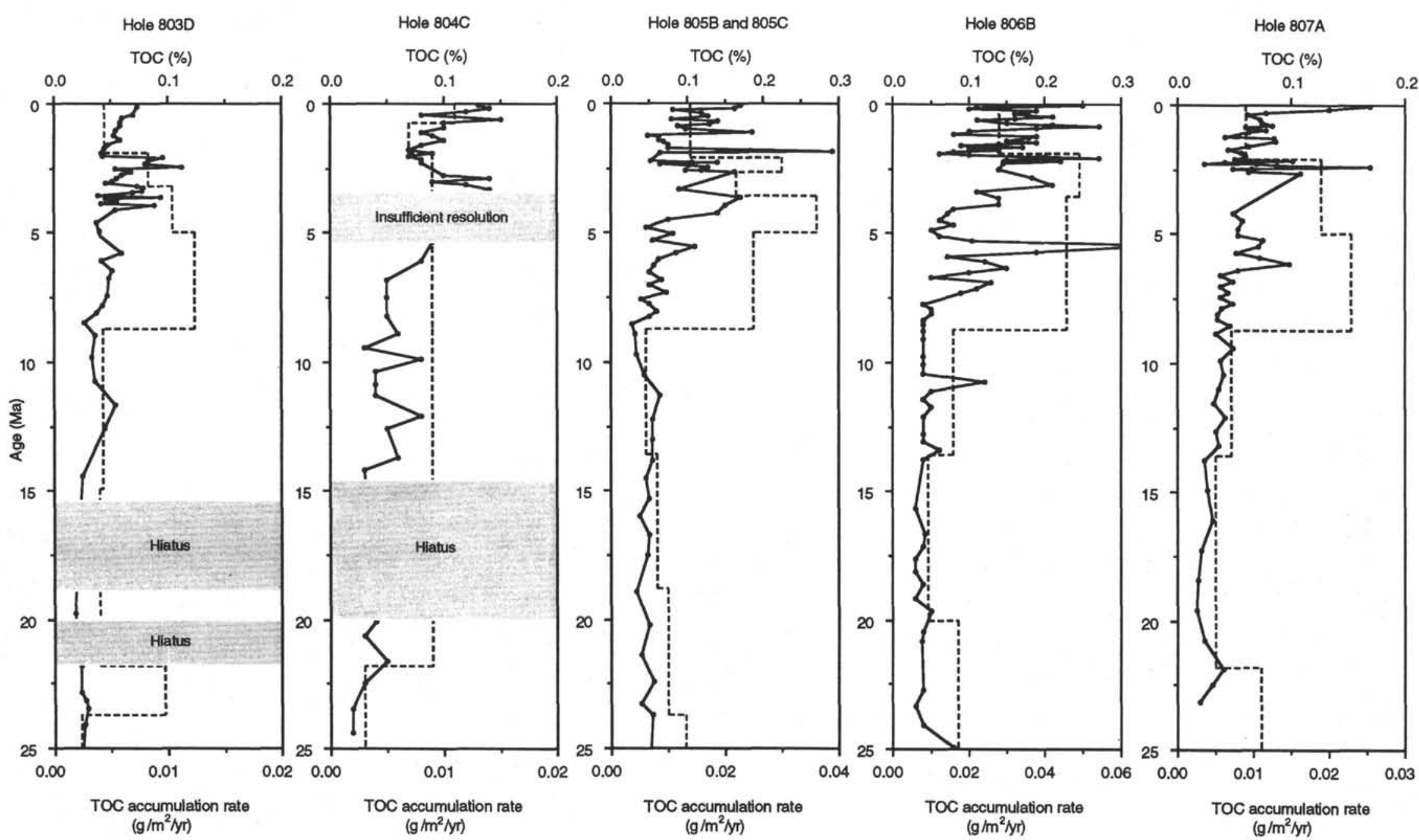

Figure 2. Total organic carbon (TOC) values and accumulation rates vs. age. The accumulation rates are shown as the average rates between stratigraphic datum levels used as absolute time constraints. 


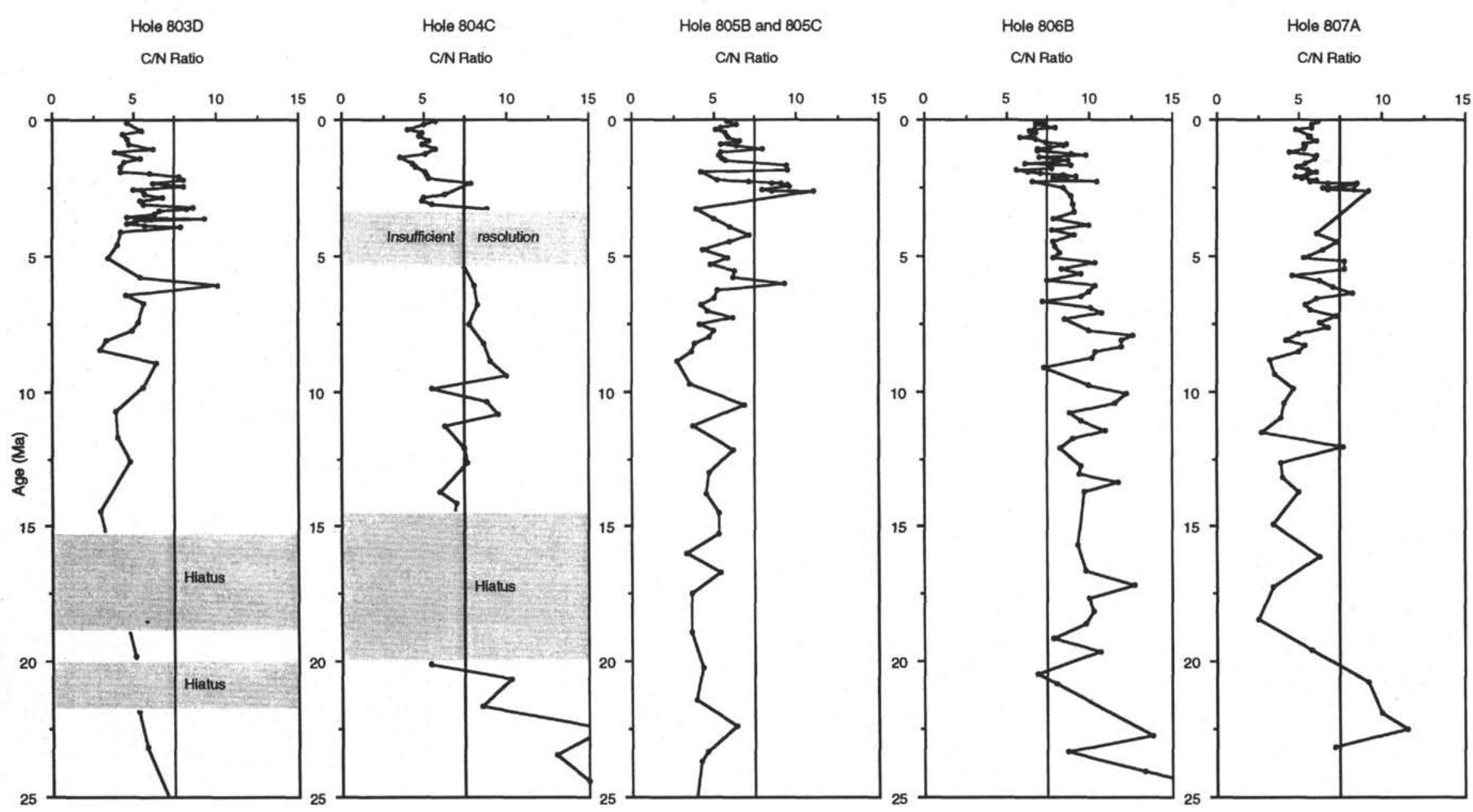

Figure 3. $\mathrm{C} / \mathrm{N}$ ratios calculated using carbon and nitrogen values of the carbonate-free residue of the samples. 


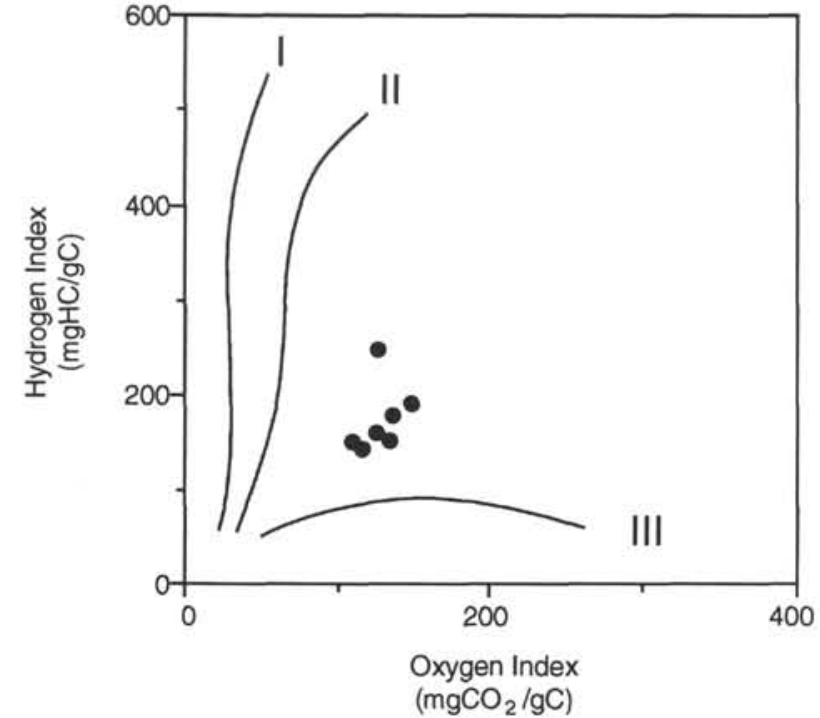

Figure 4. Hydrogen vs. oxygen indexes ("van Krevelen diagram") of organic matter from carbonate-free samples, Site 806 .

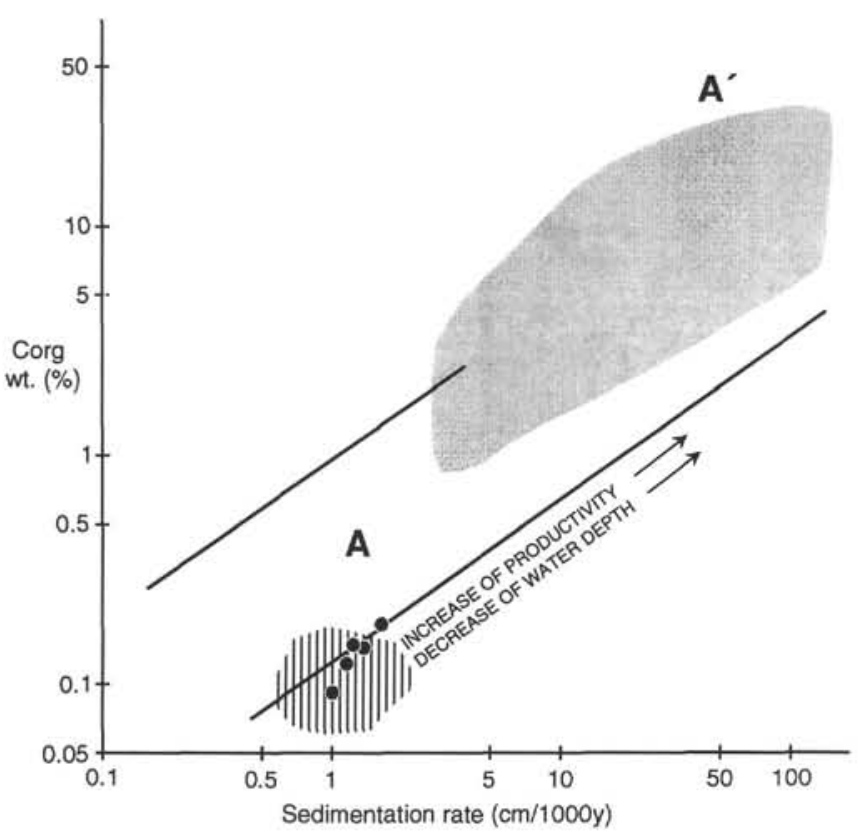

Figure 5. Correlation between sedimentation rate and organic carbon in oxic marine environments. The distinction between Fields A (oxic deep-water conditions) and $\mathrm{A}^{\prime}$ (high oceanic productivity) is derived from Holocene to Miocene sediments (Müller and Suess, 1979; Stein, 1986a, 1990). The small hachured area indicates the data points of Leg 130 sediments; solid dots are data from the surface sediment of Sites 803 through 807.

\section{ACKNOWLEDGMENTS}

We thank Drs. G. Bohrmann, M. Zhao, and P. A. Meyers for insightful comments on the manuscript. Technical assistance by $\mathrm{A}$. Korytowski, E. Steinmetz, E. Thei $\beta$, and A. Trapp is gratefully acknowledged. Financial support was provided by the Deutsche Forschungsgemeinschaft (Grant No. STE 412/3). This is contribution No. 525 of the Alfred-Wegener Institute for Polar and Marine Research.

\section{REFERENCES}

Andrews, J.E., Packham, G.H., et al., 1975. Init. Repts. DSDP, 30: Washington (U.S. Govt. Printing Office).

Berger, W.H., in press. Produktivität des Ozeans aus geologischer Sicht: Denkmodelle und Beispiele. Z. Dt. Geol. Ges.

Berger, W.H., Smetacek, V., and Wefer, G., 1989. Productivity of the Ocean: Past and Present. Life Sci. Res. Rep., 44: New York (Wiley).

Berger, W.H., and Johnson, T.C., 1976. Deep-sea carbonates: dissolution and mass wasting on the Ontong Java Plateau. Science, 192:785-787.

Betzer, P.R., Showers, W.J., Laws, E.A., Winn, C.D., Ditullo, G.R., and Kroopnick, P.M., 1984. Primary productivity and particle fluxes on a transect of the equator at $153^{\circ} \mathrm{W}$ in the Pacific Ocean. Deep-sea Res., Pt. A, 31:1-11.

Bordowskiy, O.K., 1965a. Accumulation of organic matter in bottom sediments. Mar. Geol., 3:33-82.

Emeis, K.-C., and Kvenvolden, K.A., 1986. Shipboard organic geochemistry on JOIDES Resolution. ODP Tech. Note, No. 7.

1965b. Sources of organic matter in marine basins. Mar. Geol., 3:5-31.

Emerson, S., 1985. Organic carbon preservation in marine sediments. In Sundquist, E.T., and Broecker, W.S. (Eds.), The Carbon Cycle and Atmospheric $\mathrm{CO}_{2}$ : Natural Variations Archean to Present. Geophys. Monogr., 32:78-89.

Emerson, S., Fischer, K., Reimers, C., and Heggie, D., 1985. Organic carbon dynamics and preservation in deep-sea sediments. Deep-sea Res., Pt. A, 32:1-22.

Eppley, R.W., 1989. New Production: History, Methods, Problems. In Berger, W. H., Smetacek, V., and Wefer, G. (Eds.), Productivity of the Ocean: Past and Present. Life Sci. Res. Rep., 44: New York (Wiley), 85-98.

Espitalié, J., Laporte, J.L., Madec, M., Marquis, F., Leplat, P., Paulet, J., and Boutefeu, A., 1977. Méthode rapide de characterisation des roches-mere, de leur potential petrolier et de leur degree d'evolution. Rev. Inst. Franc. Petrol., 32:23-42.

Koblents-Mishke, O.I., Volkovinsky, V.V., and Kabanova, Y.G., 1970. Plankton primary production of the World Ocean. In Wooster, W. (Ed.), Scientific Exploration of the South Pacific: Washington (Nat. Acad. Sci.), 183-193.

Kroenke, L.W., Berger, W.H., Janecek, T.R., et al., 1991. Proc. ODP, Init. Repts., 130: College Station, TX (Ocean Drilling Program).

Macko, S.A., and Pereira, C.P.G., 1990. Neogene paleoclimate development of the Antarctic Weddell Sea region: organic geochemistry. In Barker, P.F., Kennett, J.P., et al., Proc. ODP, Sci. Results, 113: College Station, TX (Ocean Drilling Program), 881-893.

Mayer, L.A., Shipley, T.H., and Winterer, E.L., 1986. Equatorial Pacific seismic reflectors as indicators of global oceanographic events. Science, 233:761-764.

Moberly, R., Schlanger, S.O., et al., 1986. Init. Repts. DSDP, 89: Washington (U.S. Govt. Printing Office).

Müller, P.J., 1977. C/N ratios in Pacific deep-sea sediments: effect of inorganic ammonium and organic nitrogen compounds sorbed by clays. Geochim. Cosmochim. Acta, 41:765-776.

Müller, P.J., and Suess, E., 1979. Productivity, sedimentation rate, and sedimentary organic matter in the oceans. I. Organic matter preservation. Deep-sea Res., Pt. A, 26:1347-1362.

Pedersen, T.F., Nielsen, B., and Pickering, M., 1991. Timing of late Quaternary productivity pulses in the Panama Basin and implications for atmospheric $\mathrm{CO}_{2}$. Paleoceanography, 6:657-677.

Romankevich, E.A., 1984. Geochemistry of Organic Matter in the Ocean: Berlin (Springer-Verlag).

Sarnthein, M., Winn, K., and Zahn, R., 1987. Paleoproductivity of oceanic upwelling and the effect on atmospheric $\mathrm{CO}_{2}$ and climatic change during deglaciation times. In Berger, W.H., and Labeyrie, L. (Eds.), Abrupt Climatic Change: Dordrecht (Riedel), 311-337.

Scheffer, F., and Schachtschabel, P., 1984. Lehrbuch der Bodenkunde: Stuttgart (F. Enke).

Stein, R., 1986a. Organic carbon and sedimentation rate- further evidence for anoxic deep-water conditions in the Cenomanian/Turonian Atlantic Ocean. Mar. Geol., 72:199-209.

, 1986b. Surface-water paleo-productivity as inferred from sediments deposited in oxic and anoxic deep-water environments of the Mesozoic Atlantic Ocean. In Degens, E.T., Meyers, P.A., and Brassel, S.C. (Eds.), Biochemistry of Black Shales. Mitt. Geol. Paläont. Inst. Univ. Hamburg, 60:55-70. 
1990. Organic carbon content/sedimentation rate relationship and its paleoenvironmental significance for marine sediments. Geo. Mar. Lett., 10:37-44.

1991. Accumulation of organic carbon in marine sediments. Lect. Earth Sci., 34: Berlin (Springer-Verlag).

Stein, R., Littke, R., Stax, R., and Welte, D.H., 1989. Quantity, provenance, and maturity of organic matter at ODP Sites 645, 646, and 647: implications for reconstruction of paleoenvironments in Baffin Bay and Labrador Sea during Tertiary and Quaternary time. In Srivastava, S.P., Arthur, M.A., et al., Proc. ODP, Sci. Results, 105: College Station, TX (Ocean Drilling Program), 185-208.

Suess, E., 1980. Particulate organic carbon flux in the oceans-surface productivity and oxygen utilisation. Nature, 288:260-263.

Ten Haven, H.L., Littke, R., Rullkötter, J., Stein, R., and Welte, D.H., 1990. Accumulation rates and composition of organic matter in late Cenozoic sediments underlying the active upwelling area off Peru. In Suess, E., von Huene, R., et al., Proc. ODP, Sci. Results, 112: College Station, TX (Ocean Drilling Program), 591-606.
Van Andel, T.H., Heath, G.R., and Moore, T.C., 1975. Cenozoic history and paleoceanography of the central equatorial Pacific Ocean. Mem. Geol. Soc. Am., No. 143.

Walsh, J.J., 1989. How much shelf production reaches the deep sea? In Berger, W.H., Smetacek, V., and Wefer, G. (Eds.), Productivity of the Ocean: Past and Present. Life Sci. Res. Rep., 44: New York (Wiley), 175-192.

Waples, D.W., and Sloan, J.R., 1980. Carbon and nitrogen diagenesis in deep sea sediments. Geochim. Cosmochim. Acta, 44:1463-1470.

Winterer, E.L., Riedel, W.R., et al., 1971. Init. Repts. DSDP, 7, Pts. 1 and 2: Washington (U.S. Govt. Printing Office).

Date of initial receipt: 20 September 1991

Date of acceptance: 21 March 1992

Ms 130B-039 
APPENDIX

Accumulation Rates of Bulk Sediment and Total Organic Carbon, Leg 130

\begin{tabular}{|c|c|c|c|c|c|c|c|c|}
\hline \multirow[b]{2}{*}{$\begin{array}{l}\text { Core, section, } \\
\text { interval }(\mathrm{cm})\end{array}$} & \multirow[b]{2}{*}{$\begin{array}{l}\text { Depth } \\
\text { (mbsf) }\end{array}$} & \multirow[b]{2}{*}{$\begin{array}{l}\text { Age } \\
\text { (Ma) }\end{array}$} & \multirow[b]{2}{*}{$\begin{array}{c}\text { Bulk } \\
\text { accumulation rate } \\
\left(\mathrm{g} / \mathrm{m}^{2} / \mathrm{yr}\right)\end{array}$} & \multirow[b]{2}{*}{$\begin{array}{c}\text { TOC } \\
\text { accumulation rate } \\
\left(\mathrm{g} / \mathrm{m}^{2} / \mathrm{yr}\right)\end{array}$} & \multirow[b]{2}{*}{$\begin{array}{l}\text { TOC } \\
(\%)\end{array}$} & \multicolumn{3}{|c|}{ Carbonate-free residue } \\
\hline & & & & & & $\begin{array}{l}\text { TOC' } \\
(\%)\end{array}$ & $\begin{array}{l}\mathrm{N}^{\prime} \\
(\%)\end{array}$ & $\mathrm{TOC}^{\prime} / \mathrm{N}^{\prime}$ \\
\hline \multicolumn{9}{|l|}{$130-803 \mathrm{D}-$} \\
\hline $1 \mathrm{H}-1,129$ & 1.29 & 0.14 & 6.53 & 0.005 & 0.07 & 0.47 & 0.10 & 4.6 \\
\hline $2 \mathrm{H}-1,129$ & 3.79 & 0.40 & 7.56 & 0.005 & 0.07 & 0.57 & 0.10 & 5.4 \\
\hline $2 \mathrm{H}-2,129$ & 5.29 & 0.57 & 8.02 & 0.005 & 0.06 & 0.47 & 0.11 & 4.3 \\
\hline $2 \mathrm{H}-3,129$ & 6.79 & 0.73 & 7.54 & 0.004 & 0.06 & 0.41 & 0.09 & 4.7 \\
\hline $2 \mathrm{H}-4,117$ & 8.17 & 0.87 & 7.66 & 0.005 & 0.06 & 0.48 & 0.10 & 4.7 \\
\hline $2 \mathrm{H}-5,129$ & 9.79 & 1.05 & 7.86 & 0.004 & 0.05 & 0.48 & 0.08 & 6.2 \\
\hline $2 \mathrm{H}-6,129$ & 11.29 & 1.21 & 7.96 & 0.004 & 0.05 & 0.35 & 0.09 & 3.9 \\
\hline $3 \mathrm{H}-1,129$ & 13.29 & 1.42 & 7.62 & 0.005 & 0.06 & 0.35 & 0.07 & 5.4 \\
\hline $3 \mathrm{H}-2,129$ & 14.79 & 1.58 & 7.88 & 0.004 & 0.05 & 0.43 & 0.10 & 4.4 \\
\hline $3 \mathrm{H}-3,129$ & 16.29 & 1.74 & 8.48 & 0.004 & 0.05 & 0.34 & 0.08 & 4.2 \\
\hline $3 \mathrm{H}-4,13 \mathrm{I}$ & 17.81 & 1.89 & 12.56 & 0.005 & 0.04 & 0.33 & 0.08 & 4.3 \\
\hline $3 \mathrm{H}-5,13 \mathrm{O}$ & 19.30 & 2.00 & 12.15 & 0.005 & 0.04 & 0.37 & 0.06 & 5.9 \\
\hline $3 \mathrm{H}-6,128$ & 20.78 & 2.10 & 12.74 & 0.012 & 0.10 & 0.95 & 0.12 & 7.8 \\
\hline $4 \mathrm{H}-1,129$ & 22.79 & 2.24 & 13.09 & 0.011 & 0.08 & 0.69 & 0.09 & 8.1 \\
\hline $4 \mathrm{H}-2,129$ & 24.29 & 2.34 & 12.60 & 0.010 & 0.08 & 0.70 & 0.11 & 6.1 \\
\hline $4 \mathrm{H}-3,130$ & 25.80 & 2.44 & 11.46 & 0.013 & 0.11 & 1.03 & 0.13 & 8.1 \\
\hline $4 \mathrm{H}-4,128$ & 27.28 & 2.55 & 12.50 & 0.007 & 0.05 & 0.45 & 0.09 & 5.0 \\
\hline $4 \mathrm{H}-5,129$ & 28.79 & 2.65 & 13.76 & 0.009 & 0.07 & 0.56 & 0.10 & 5.6 \\
\hline $4 \mathrm{H}-6,129$ & 30.29 & 2.75 & 12.96 & 0.008 & 0.06 & 0.60 & 0.11 & 5.7 \\
\hline $5 \mathrm{H}-1,132$ & 32.32 & 2.89 & 12.91 & 0.007 & 0.06 & 0.53 & 0.08 & 6.7 \\
\hline $5 \mathrm{H}-2,137$ & 33.87 & 3.00 & 13.05 & 0.007 & 0.05 & 0.47 & 0.09 & 5.4 \\
\hline $5 \mathrm{H}-3,129$ & 35.29 & 3.10 & 13.43 & 0.006 & 0.05 & 0.36 & 0.06 & 5.6 \\
\hline $5 \mathrm{H}-4,129$ & 36.79 & 3.20 & 16.89 & 0.012 & 0.07 & 0.63 & 0.07 & 8.6 \\
\hline $5 \mathrm{H}-5,129$ & 38.29 & 3.28 & 15.93 & 0.013 & 0.08 & 0.68 & 0.08 & 8.3 \\
\hline 5H-6, 129 & 39.79 & 3.36 & 16.81 & 0.013 & 0.08 & 0.67 & 0.10 & 6.6 \\
\hline $6 \mathrm{H}-1,129$ & 41.79 & 3.47 & 15.89 & 0.011 & 0.07 & 0.51 & 0.08 & 6.3 \\
\hline $6 \mathrm{H}-2,129$ & 43.29 & 3.55 & 15.93 & 0.006 & 0.04 & 0.44 & 0.10 & 4.6 \\
\hline $6 \mathrm{H}-3,129$ & 44.79 & 3.63 & 16.35 & 0.016 & 0.10 & 0.98 & 0.11 & 9.3 \\
\hline $6 \mathrm{H}-4,98$ & 45.98 & 3.70 & 16.32 & 0.008 & 0.05 & 0.38 & 0.07 & 5.2 \\
\hline $6 \mathrm{H}-5,129$ & 47.79 & 3.80 & 16.11 & 0.009 & 0.06 & 0.36 & 0.08 & 4.6 \\
\hline $6 \mathrm{H}-6,129$ & 49.29 & 3.88 & 16.86 & 0.007 & 0.04 & 0.35 & 0.06 & 5.7 \\
\hline $6 \mathrm{H}-7,42$ & 49.92 & 3.91 & 16.26 & 0.015 & 0.09 & 0.59 & 0.08 & 7.8 \\
\hline $7 \mathrm{H}-5,129$ & 53.39 & 4.10 & 17.59 & 0.010 & 0.05 & 0.55 & 0.13 & 4.2 \\
\hline $8 \mathrm{H}-5,129$ & 62.89 & 4.62 & 17.13 & 0.007 & 0.04 & 0.49 & 0.12 & 4.0 \\
\hline $9 H-5,129$ & 72.39 & 5.09 & 25.43 & 0.010 & 0.04 & 0.44 & 0.13 & 3.4 \\
\hline $11 \mathrm{H}-5,129$ & 91.39 & 5.76 & 28.45 & 0.017 & 0.06 & 0.82 & 0.15 & 5.4 \\
\hline $12 \mathrm{H}-5,129$ & 100.89 & 6.10 & 29.02 & 0.012 & 0.04 & 0.72 & 0.07 & 10.1 \\
\hline $13 \mathrm{H}-5,129$ & 110.39 & 6.44 & 27.54 & 0.014 & 0.05 & 0.63 & 0.14 & 4.5 \\
\hline $14 \mathrm{H}-5,129$ & 119.89 & 6.77 & 29.44 & 0.014 & 0.05 & 0.64 & 0.12 & 5.6 \\
\hline $16 \mathrm{H}-5,129$ & 138.89 & 7.44 & 27.28 & 0.013 & 0.05 & 0.61 & 0.12 & 5.3 \\
\hline $17 \mathrm{H}-5,129$ & 148.39 & 7.78 & 29.56 & 0.013 & 0.04 & 0.52 & 0.11 & 4.9 \\
\hline $18 \mathrm{H}-5,129$ & 157.89 & 8.12 & 27.22 & 0.010 & 0.04 & 0.34 & 0.10 & 3.3 \\
\hline $19 \mathrm{H}-5,129$ & 167.39 & 8.45 & 29.62 & 0.008 & 0.03 & 0.34 & 0.11 & 3.0 \\
\hline $20 \mathrm{H}-5,129$ & 176.89 & 8.94 & 11.29 & 0.004 & 0.04 & 0.25 & 0.04 & 6.4 \\
\hline $21 \mathrm{H}-5,129$ & 186.39 & 9.85 & 11.63 & 0.004 & 0.03 & 0.39 & 0.07 & 5.5 \\
\hline $22 \mathrm{H}-5,129$ & 195.89 & 10.76 & 11.55 & 0.004 & 0.04 & 0.42 & 0.11 & 4.0 \\
\hline $23 \mathrm{H}-5,129$ & 205.39 & 11.67 & 10.05 & 0.005 & 0.05 & 0.32 & 0.08 & 4.0 \\
\hline $24 \mathrm{H}-5,129$ & 214.89 & 12.58 & 11.36 & 0.005 & 0.05 & 0.24 & 0.05 & 4.8 \\
\hline $26 \mathrm{X}-5,129$ & 234.09 & 14.42 & 12.06 & 0.003 & 0.03 & 0.32 & 0.11 & 2.9 \\
\hline $28 \mathrm{X}-4,129$ & 251.69 & 19.79 & 21.91 & 0.004 & 0.02 & 0.18 & 0.04 & 5.1 \\
\hline $29 \mathrm{X}-4,129$ & 261.29 & 21.83 & 39.28 & 0.009 & 0.02 & 0.43 & 0.08 & 5.3 \\
\hline $32 \mathrm{X}-5,124$ & 291.54 & 22.83 & 38.42 & 0.009 & 0.02 & 0.38 & & \\
\hline $33 \mathrm{X}-5,126$ & 301.36 & 23.16 & 37.14 & 0.010 & 0.03 & 0.40 & 0.07 & 5.8 \\
\hline $34 \mathrm{X}-5,123$ & 310.53 & 23.46 & 35.99 & 0.011 & 0.03 & 0.39 & & \\
\hline $35 X-5,134$ & 320.34 & 24.09 & 8.29 & 0.002 & 0.03 & 0.43 & & \\
\hline \multicolumn{9}{|l|}{$130-804 \mathrm{C}$ - } \\
\hline $1 \mathrm{H}-1,72$ & 0.72 & 0.06 & 8.31 & 0.010 & 0.13 & 0.62 & 0.11 & 5.7 \\
\hline $1 \mathrm{H}-2,72$ & 2.22 & 0.20 & 8.64 & 0.013 & 0.14 & 0.46 & 0.09 & 5.0 \\
\hline $1 \mathrm{H}-3,72$ & 3.72 & 0.33 & 9.21 & 0.011 & 0.12 & 0.39 & 0.10 & 4.1 \\
\hline $1 \mathrm{H}-4.72$ & 5.22 & 0.46 & 9.32 & 0.007 & 0.08 & 0.44 & 0.09 & 4.9 \\
\hline $2 \mathrm{H}-1,72$ & 7.02 & 0.62 & 7.93 & 0.012 & 0.15 & 0.44 & 0.09 & 4.7 \\
\hline $2 \mathrm{H}-2,72$ & 8.52 & 0.76 & 7.91 & 0.008 & 0.10 & 0.38 & 0.07 & 5.3 \\
\hline $2 \mathrm{H}-3,72$ & 10.02 & 0.92 & 8.43 & 0.008 & 0.10 & 0.52 & 0.11 & 4.9 \\
\hline $2 \mathrm{H}-4,72$ & 11.52 & 1.08 & 8.16 & 0.006 & 0.08 & 0.40 & 0.07 & 5.7 \\
\hline $2 \mathrm{H}-5,72$ & 13.02 & 1.23 & 7.89 & 0.007 & 0.09 & 0.36 & 0.07 & 5.1 \\
\hline $2 \mathrm{H}-6,72$ & 14.52 & 1.39 & 7.74 & 0.008 & 0.10 & 0.44 & 0.13 & 3.5 \\
\hline $3 \mathrm{H}-1,72$ & 16.52 & 1.60 & 7.88 & 0.006 & 0.08 & 0.45 & 0.10 & 4.3 \\
\hline $3 \mathrm{H}-2,72$ & 18.02 & 1.76 & 8.66 & 0.006 & 0.07 & 0.32 & 0.07 & 4.5 \\
\hline $3 \mathrm{H}-3,72$ & 19.52 & 1.91 & 9.06 & 0.008 & 0.09 & 0.37 & 0.07 & 5.1 \\
\hline
\end{tabular}


Appendix (continued).

\begin{tabular}{|c|c|c|c|c|c|c|c|c|}
\hline \multirow[b]{2}{*}{$\begin{array}{l}\text { Core, section, } \\
\text { interval }(\mathrm{cm})\end{array}$} & \multirow[b]{2}{*}{$\begin{array}{l}\text { Depth } \\
\text { (mbsf) }\end{array}$} & \multirow[b]{2}{*}{$\begin{array}{l}\text { Age } \\
\text { (Ma) }\end{array}$} & \multirow{2}{*}{$\begin{array}{c}\text { Bulk } \\
\text { accumulation rate } \\
\left(\mathrm{g} / \mathrm{m}^{2} / \mathrm{yr}\right)\end{array}$} & \multirow{2}{*}{$\begin{array}{c}\text { TOC } \\
\text { accumulation rate } \\
\left(\mathrm{g} / \mathrm{m}^{2} / \mathrm{yr}\right)\end{array}$} & \multirow[b]{2}{*}{$\begin{array}{l}\text { TOC } \\
(\%)\end{array}$} & \multicolumn{3}{|c|}{ Carbonate-free residue } \\
\hline & & & & & & $\begin{array}{l}\mathrm{TOC}^{\prime} \\
(\%)\end{array}$ & $\begin{array}{c}\mathrm{N}^{\prime} \\
(\%)\end{array}$ & $\mathrm{TOC}^{\prime} / \mathrm{N}^{\prime}$ \\
\hline $3 \mathrm{H}-5,72$ & 22.52 & 2.17 & 9.43 & 0.008 & 0.08 & 0.53 & 0.10 & 5.3 \\
\hline $3 \mathrm{H}-6,72$ & 24.02 & 2.30 & 8.92 & 0.007 & 0.08 & 0.43 & 0.06 & 7.9 \\
\hline $4 \mathrm{H}-3,96$ & 29.26 & 2.75 & 9.48 & 0.010 & 0.10 & 0.54 & 0.09 & 6.3 \\
\hline $4 \mathrm{H}-4,72$ & 30.52 & 2.86 & 8.51 & 0.012 & 0.14 & 0.67 & 0.13 & 5.0 \\
\hline $4 \mathrm{H}-5,72$ & 32.02 & 2.99 & 9.42 & 0.008 & 0.09 & 0.44 & 0.09 & 4.9 \\
\hline $4 \mathrm{H}-6,68$ & 33.48 & 3.12 & 9.64 & 0.011 & 0.12 & 0.59 & 0.11 & 5.5 \\
\hline $4 \mathrm{H}-7,68$ & 34.98 & 3.29 & & & 0.14 & 0.91 & 0.10 & 8.8 \\
\hline $5 \mathrm{H}-4,72$ & 40.02 & 3.97 & & & 0.10 & 0.39 & 0.08 & 5.2 \\
\hline $5 \mathrm{H}-5,72$ & 41.52 & 4.18 & & & 0.09 & 0.33 & 0.06 & 5.5 \\
\hline $5 \mathrm{H}-6,72$ & 43.02 & 4.38 & & & 0.09 & 0.28 & 0.09 & 3.2 \\
\hline $6 \mathrm{H}-1,72$ & 45.02 & 4.65 & & & 0.07 & 0.53 & 0.08 & 6.4 \\
\hline $6 \mathrm{H}-2,72$ & 46.52 & 4.86 & & & 0.08 & 0.56 & 0.11 & 5.3 \\
\hline $6 \mathrm{H}-3,72$ & 48.02 & 5.06 & & & 0.09 & 0.74 & 0.12 & 6.1 \\
\hline $6 \mathrm{H}-4,72$ & 49.52 & 5.24 & 12.49 & 0.016 & 0.13 & 0.75 & 0.12 & 6.3 \\
\hline $6 \mathrm{H}-5,72$ & 51.02 & 5.35 & 13.21 & 0.012 & 0.09 & 0.67 & 0.09 & 7.4 \\
\hline $7 \mathrm{H}-5,72$ & 60.52 & 6.07 & 14.29 & 0.011 & 0.08 & 0.72 & 0.09 & 8.0 \\
\hline $8 \mathrm{H}-5,72$ & 70.02 & 6.80 & 12.58 & 0.006 & 0.05 & 0.33 & 0.04 & 8.3 \\
\hline $9 \mathrm{H}-5,72$ & 79.52 & 7.52 & 12.89 & 0.006 & 0.05 & 0.31 & 0.04 & 7.8 \\
\hline $10 \mathrm{H}-5,72$ & 89.02 & 8.25 & 11.87 & 0.006 & 0.05 & 0.26 & 0.03 & 8.7 \\
\hline $11 \mathrm{H}-5,72$ & 98.52 & 8.90 & 18.98 & 0.011 & 0.06 & 0.36 & 0.04 & 9.0 \\
\hline $12 \mathrm{H}-5,72$ & 108.02 & 9.43 & 18.44 & 0.006 & 0.03 & 0.30 & 0.03 & 10.0 \\
\hline $13 \mathrm{H}-5,72$ & 116.02 & 9.88 & 17.68 & 0.014 & 0.08 & 0.33 & 0.06 & 5.5 \\
\hline $14 X-5,72$ & 125.52 & 10.41 & 17.66 & 0.007 & 0.04 & 0.44 & 0.05 & 8.8 \\
\hline $15 X-3,72$ & 133.52 & 10.86 & 16.20 & 0.006 & 0.04 & 0.19 & 0.02 & 9.5 \\
\hline $16 X-2,72$ & 141.52 & 11.30 & 15.78 & 0.006 & 0.04 & 0.25 & 0.04 & 6.3 \\
\hline $17 X-5,72$ & 155.52 & 12.09 & 18.96 & 0.015 & 0.08 & 0.30 & 0.04 & 7.5 \\
\hline $18 X-5,71$ & 165.01 & 12.62 & 16.97 & 0.008 & 0.05 & 0.23 & 0.03 & 7.7 \\
\hline $20 X-5,72$ & 184.42 & 13.71 & & & 0.06 & 0.30 & 0.05 & 6.0 \\
\hline $21 X-4,72$ & 192.62 & 14.17 & & & 0.03 & 0.21 & 0.03 & 7.0 \\
\hline $22 X-5,72$ & 203.82 & 20.10 & 15.54 & 0.006 & 0.04 & 0.38 & 0.07 & 5.4 \\
\hline $23 X-5,72$ & 213.52 & 20.62 & 20.16 & 0.006 & 0.03 & 0.31 & 0.03 & 10.3 \\
\hline $25 X-5,86$ & 233.06 & 21.65 & 20.75 & 0.010 & 0.05 & 0.17 & 0.02 & 8.5 \\
\hline $26 X-5,72$ & 242.52 & 22.48 & 10.43 & 0.003 & 0.03 & 0.16 & 0.01 & 16.0 \\
\hline $27 X-5,70$ & 252.10 & 23.44 & 11.30 & 0.002 & 0.02 & 0.13 & 0.01 & 13.0 \\
\hline $28 X-5,43$ & 261.53 & 24.39 & 12.86 & 0.003 & 0.02 & 0.15 & 0.01 & 15.0 \\
\hline $29 X-5,72$ & 271.42 & & & & 0.02 & 0.10 & 0.01 & 7.3 \\
\hline $30 x-5,72$ & 281.12 & & & & 0.04 & 0.44 & 0.05 & 8.8 \\
\hline $31 X-5,72$ & 290.72 & & & & 0.04 & 0.37 & 0.03 & 12.3 \\
\hline $32 X-5,72$ & 300.42 & & & & 0.06 & 0.80 & 0.07 & 11.4 \\
\hline $33 X-5,72$ & 309.81 & & & & 0.04 & 0.25 & 0.02 & 12.5 \\
\hline \multicolumn{9}{|l|}{$130-805 C-$} \\
\hline $1 \mathrm{H}-1,112$ & 1.12 & 0.07 & 10.94 & 0.019 & 0.17 & 1.09 & 0.19 & 5.8 \\
\hline $1 \mathrm{H}-2,112$ & 2.62 & 0.17 & 10.96 & 0.018 & 0.16 & 1.26 & 0.20 & 6.4 \\
\hline $1 \mathrm{H}-3,112$ & 4.12 & 0.27 & 11.94 & 0.010 & 0.08 & 0.73 & 0.13 & 5.4 \\
\hline $1 \mathrm{H}-4,112$ & 5.62 & 0.37 & 12.17 & 0.014 & 0.12 & 0.62 & 0.12 & 5.1 \\
\hline $1 \mathrm{H}-5,112$ & 7.12 & 0.47 & 11.99 & 0.015 & 0.13 & 0.81 & 0.14 & 5.7 \\
\hline $2 \mathrm{H}-1,112$ & 8.92 & 0.59 & 12.54 & 0.010 & 0.08 & 0.69 & 0.12 & 5.8 \\
\hline $2 \mathrm{H}-2,112$ & 10.42 & 0.68 & 12.59 & 0.018 & 0.14 & 0.83 & 0.14 & 5.9 \\
\hline $2 \mathrm{H}-3,112$ & 11.92 & 0.78 & 12.59 & 0.016 & 0.13 & 0.96 & 0.15 & 6.6 \\
\hline $2 \mathrm{H}-4,112$ & 13.42 & 0.88 & 12.83 & 0.011 & 0.09 & 0.60 & 0.11 & 5.4 \\
\hline $2 \mathrm{H}-5,112$ & 14.92 & 0.98 & 12.53 & 0.012 & 0.10 & 0.75 & 0.12 & 6.4 \\
\hline $2 \mathrm{H}-6,112$ & 16.42 & 1.08 & 12.69 & 0.024 & 0.19 & 1.25 & 0.16 & 7.9 \\
\hline $3 \mathrm{H}-1,112$ & 18.42 & 1.21 & 12.69 & 0.006 & 0.05 & 0.56 & 0.10 & 5.4 \\
\hline $3 \mathrm{H}-2,112$ & 19.92 & 1.31 & 12.71 & 0.008 & 0.06 & 0.65 & 0.12 & 5.3 \\
\hline $3 \mathrm{H}-3,112$ & 21.42 & 1.41 & 12.91 & 0.008 & 0.06 & 0.51 & 0.09 & 5.5 \\
\hline $3 \mathrm{H}-4,112$ & 22.92 & 1.50 & 12.88 & 0.009 & 0.07 & 0.53 & 0.09 & 5.7 \\
\hline $3 \mathrm{H}-5,112$ & 24.42 & 1.60 & 12.91 & 0.010 & 0.07 & 0.51 & & \\
\hline $3 \mathrm{H}-6,112$ & 25.92 & 1.70 & 12.91 & 0.009 & 0.07 & 0.53 & 0.06 & 9.4 \\
\hline $4 \mathrm{H}-1,112$ & 27.92 & 1.83 & 13.95 & 0.041 & 0.29 & 1.60 & 0.17 & 9.5 \\
\hline $4 \mathrm{H}-2,112$ & 29.42 & 1.93 & 12.07 & 0.008 & 0.07 & 0.48 & 0.11 & 4.2 \\
\hline $4 \mathrm{H}-6,112$ & 35.42 & 2.19 & 26.77 & 0.014 & 0.05 & 0.60 & 0.12 & 5.2 \\
\hline $5 \mathrm{H}-1,112$ & 37.42 & 2.25 & 27.61 & 0.029 & 0.11 & 0.88 & 0.12 & 7.2 \\
\hline $5 \mathrm{H}-2,112$ & 38.92 & 2.30 & 27.61 & 0.038 & 0.14 & 1.08 & 0.12 & 9.1 \\
\hline $5 \mathrm{H}-3,112$ & 40.42 & 2.35 & 29.36 & 0.019 & 0.06 & 0.80 & 0.09 & 8.5 \\
\hline $5 \mathrm{H}-4,112$ & 41.92 & 2.40 & 27.55 & 0.028 & 0.10 & 1.05 & 0.11 & 9.5 \\
\hline $5 \mathrm{H}-5,112$ & 43.42 & 2.44 & 25.61 & 0.033 & 0.13 & 1.18 & 0.12 & 9.6 \\
\hline $6 \mathrm{H}-1,112$ & 46.92 & 2.55 & 29.90 & 0.035 & 0.12 & 0.84 & 0.11 & 7.9 \\
\hline $6 \mathrm{H}-2,116$ & 48.46 & 2.60 & 26.32 & 0.026 & 0.10 & 1.02 & 0.12 & 8.5 \\
\hline $6 \mathrm{H}-3,115$ & 49.95 & 2.65 & 30.15 & 0.049 & 0.16 & 1.22 & 0.11 & 11.1 \\
\hline $130-805 \mathrm{~B}-$ & & & & & & & & \\
\hline $8 \mathrm{H}-5,112$ & 70.82 & 3.30 & 25.05 & 0.022 & 0.09 & 0.65 & 0.17 & 3.9 \\
\hline
\end{tabular}


Appendix (continued).

\begin{tabular}{|c|c|c|c|c|c|c|c|c|}
\hline \multirow[b]{2}{*}{$\begin{array}{l}\text { Core, section, } \\
\text { interval }(\mathrm{cm})\end{array}$} & \multirow[b]{2}{*}{$\begin{array}{l}\text { Depth } \\
\text { (mbsf) }\end{array}$} & \multirow[b]{2}{*}{$\begin{array}{l}\text { Age } \\
\text { (Ma) }\end{array}$} & \multirow[b]{2}{*}{$\begin{array}{c}\text { Bulk } \\
\text { accumulation rate } \\
\left(\mathrm{g} / \mathrm{m}^{2} / \mathrm{yr}\right)\end{array}$} & \multirow[b]{2}{*}{$\begin{array}{c}\text { TOC } \\
\text { accumulation rate } \\
\left(\mathrm{g} / \mathrm{m}^{2} / \mathrm{yr}\right)\end{array}$} & \multirow[b]{2}{*}{$\begin{array}{l}\text { TOC } \\
(\%)\end{array}$} & \multicolumn{3}{|c|}{ Carbonate-free residue } \\
\hline & & & & & & $\begin{array}{l}\text { TOC } \\
(\%)\end{array}$ & $\begin{array}{l}\mathrm{N}^{\prime} \\
(\%)\end{array}$ & $\mathrm{TOC} / \mathrm{N}^{\prime}$ \\
\hline $9 \mathrm{H}-5,112$ & 80.32 & 3.63 & 30.83 & 0.052 & 0.17 & 1.12 & 0.22 & 5.0 \\
\hline $10 \mathrm{H}-5,113$ & 89.83 & 3.92 & 30.69 & 0.046 & 0.15 & 1.41 & 0.23 & 6.0 \\
\hline $11 \mathrm{H}-5,112$ & 99.32 & 4.21 & 32.48 & 0.045 & 0.14 & 1.41 & 0.20 & 7.2 \\
\hline $12 \mathrm{H}-5,116$ & 108.86 & 4.50 & 31.22 & 0.023 & 0.07 & 0.86 & 0.14 & 6.0 \\
\hline $13 \mathrm{H}-5,112$ & 118.32 & 4.78 & 33.39 & 0.015 & 0.05 & 0.55 & 0.13 & 4.3 \\
\hline $14 \mathrm{H}-5,112$ & 127.82 & 5.06 & 36.31 & 0.029 & 0.08 & 0.68 & 0.12 & 5.9 \\
\hline $15 \mathrm{H}-5,112$ & 137.32 & 5.31 & 40.62 & 0.022 & 0.06 & 0.72 & 0.15 & 4.8 \\
\hline $16 \mathrm{H}-5,112$ & 146.82 & 5.55 & 39.38 & 0.044 & 0.11 & 1.45 & 0.23 & 6.3 \\
\hline $17 \mathrm{H}-5,112$ & 156.32 & 5.80 & 42.30 & 0.036 & 0.09 & 1.22 & 0.20 & 6.2 \\
\hline $18 \mathrm{H}-5,112$ & 165.82 & 6.05 & 40.24 & 0.025 & 0.06 & 1.19 & 0.13 & 9.3 \\
\hline $19 \mathrm{H}-5,112$ & 175.32 & 6.29 & 40.32 & 0.022 & 0.06 & 0.91 & 0.18 & 5.2 \\
\hline $20 \mathrm{H}-5,111$ & 184.81 & 6.54 & 41.25 & 0.021 & 0.05 & 0.69 & 0.14 & 5.0 \\
\hline $21 \mathrm{H}-5,113$ & 194.33 & 6.79 & 43.77 & 0.029 & 0.07 & 1.05 & 0.25 & 4.2 \\
\hline $22 \mathrm{H}-5,113$ & 203.83 & 7.03 & 42.08 & 0.021 & 0.05 & 0.72 & 0.16 & 4.6 \\
\hline $23 \mathrm{H}-5,112$ & 213.32 & 7.28 & 38.69 & 0.028 & 0.07 & 0.79 & 0.13 & 6.2 \\
\hline $24 \mathrm{H}-5,112$ & 222.82 & 7.53 & 41.02 & 0.017 & 0.04 & 0.40 & 0.10 & 4.1 \\
\hline $25 \mathrm{H}-5,112$ & 232.32 & 7.77 & 40.90 & 0.020 & 0.05 & 0.66 & 0.13 & 5.0 \\
\hline $26 \mathrm{H}-5,112$ & 241.82 & 8.02 & 41.18 & 0.025 & 0.06 & 0.49 & 0.10 & 4.7 \\
\hline $27 \mathrm{H}-5,112$ & 249.91 & 8.23 & 38.03 & 0.019 & 0.05 & 0.40 & 0.10 & 3.8 \\
\hline $28 \mathrm{H}-5,112$ & 260.82 & 8.51 & 41.32 & 0.012 & 0.03 & 0.30 & 0.08 & 3.6 \\
\hline $29 \mathrm{X}-5,112$ & 270.32 & 8.89 & 12.53 & 0.004 & 0.03 & 0.33 & 0.12 & 2.7 \\
\hline $30 X-5,112$ & 280.02 & 9.73 & 12.84 & 0.004 & 0.03 & 0.37 & 0.10 & 3.5 \\
\hline $31 X-5,112$ & 289.62 & 10.50 & 13.74 & 0.006 & 0.04 & 0.51 & 0.07 & 6.9 \\
\hline $32 X-4,112$ & 297.82 & 11.30 & 14.06 & 0.009 & 0.07 & 0.50 & 0.14 & 3.7 \\
\hline $33 \mathrm{X}-5,112$ & 308.52 & 12.20 & 13.74 & 0.007 & 0.05 & 0.80 & 0.13 & 6.2 \\
\hline $34 X-5,112$ & 318.12 & 13.00 & 12.63 & 0.007 & 0.06 & 0.45 & 0.10 & 4.7 \\
\hline $35 X-5,112$ & 327.62 & 13.80 & 16.10 & 0.009 & 0.06 & 0.55 & 0.12 & 4.5 \\
\hline $36 X-5,112$ & 337.12 & 14.50 & 17.64 & 0.008 & 0.05 & 0.49 & 0.09 & 5.3 \\
\hline $37 X-5,112$ & 346.82 & 15.30 & 15.41 & 0.008 & 0.05 & 0.51 & 0.10 & 5.3 \\
\hline $38 \mathrm{X}-5,112$ & 356.52 & 16.00 & 15.86 & 0.006 & 0.04 & 0.41 & 0.12 & 3.3 \\
\hline $39 X-5,112$ & 366.12 & 16.70 & 15.79 & 0.008 & 0.05 & 0.65 & 0.12 & 5.4 \\
\hline $40 X-5,112$ & 375.82 & 17.50 & 15.95 & 0.008 & 0.05 & 0.36 & 0.10 & 3.6 \\
\hline $42 X-5,110$ & 395.10 & 18.90 & 22.15 & 0.008 & 0.03 & 0.34 & 0.09 & 3.6 \\
\hline $44 X-5,112$ & 414.42 & 20.20 & 20.81 & 0.010 & 0.05 & 0.51 & 0.12 & 4.3 \\
\hline $46 \mathrm{X}-5,112$ & 433.62 & 21.40 & 20.53 & 0.008 & 0.04 & 0.43 & 0.11 & 3.9 \\
\hline $48 X-4,112$ & 451.12 & 22.40 & 21.12 & 0.012 & 0.06 & 0.49 & 0.08 & 6.4 \\
\hline $50 X-4,112$ & 470.42 & 23.70 & 22.28 & 0.012 & 0.05 & 0.50 & 0.12 & 4.2 \\
\hline 130-806B- & & & & & & & & \\
\hline $1 \mathrm{H}-1,121$ & 1.21 & 0.06 & 16.26 & 0.040 & 0.25 & 1.78 & 0.26 & 6.8 \\
\hline $1 \mathrm{H}-2,121$ & 2.71 & 0.13 & 15.69 & 0.018 & 0.11 & 0.68 & 0.09 & 7.3 \\
\hline $1 \mathrm{H}-3,118$ & 4.18 & 0.20 & 17.64 & 0.018 & 0.10 & 0.67 & 0.10 & 6.8 \\
\hline $1 \mathrm{H}-4,121$ & 5.71 & 0.27 & 17.01 & 0.033 & 0.19 & 1.26 & 0.16 & 7.9 \\
\hline $2 \mathrm{H}-1,120$ & 7.70 & 0.36 & 17.51 & 0.028 & 0.16 & 1.21 & 0.18 & 6.7 \\
\hline $2 \mathrm{H}-2,120$ & 9.20 & 0.43 & 17.34 & 0.031 & 0.18 & 1.12 & 0.17 & 6.4 \\
\hline $2 \mathrm{H}-3,120$ & 10.70 & 0.50 & 17.57 & 0.038 & 0.21 & 1.41 & 0.21 & 6.8 \\
\hline $2 \mathrm{H}-4,120$ & 12.20 & 0.57 & 18.30 & 0.029 & 0.16 & 1.34 & 0.21 & 6.5 \\
\hline $2 \mathrm{H}-5,12 \mathrm{I}$ & 13.70 & 0.64 & 16.78 & 0.018 & 0.11 & 0.75 & 0.13 & 5.8 \\
\hline $2 \mathrm{H}-6,120$ & 15.20 & 0.71 & 18.09 & 0.026 & 0.15 & 1.21 & 0.18 & 6.8 \\
\hline $3 \mathrm{H}-1,121$ & 17.21 & 0.81 & 19.08 & 0.039 & 0.21 & 1.55 & 0.21 & 7.4 \\
\hline $3 \mathrm{H}-2,121$ & 18.71 & 0.88 & 18.52 & 0.049 & 0.27 & 2.02 & 0.24 & 8.6 \\
\hline $3 \mathrm{H}-3,12 \mathrm{I}$ & 20.21 & 0.95 & 19.16 & 0.037 & 0.19 & 1.87 & 0.22 & 8.4 \\
\hline $3 \mathrm{H}-4,118$ & 21.68 & 1.02 & 17.77 & 0.018 & 0.10 & 0.87 & 0.11 & 7.6 \\
\hline $3 \mathrm{H}-5,121$ & 23.21 & 1.09 & 19.01 & 0.019 & 0.10 & 0.90 & 0.13 & 6.9 \\
\hline $3 \mathrm{H}-6,12 \mathrm{I}$ & 24.71 & 1.16 & 18.76 & 0.016 & 0.08 & 0.67 & 0.10 & 6.9 \\
\hline $4 \mathrm{H}-1,12 \mathrm{I}$ & 26.71 & 1.25 & 18.37 & 0.035 & 0.19 & 1.58 & 0.18 & 8.9 \\
\hline $4 \mathrm{H}-2,121$ & 28.21 & 1.32 & 19.33 & 0.035 & 0.18 & 1.80 & 0.18 & 9.8 \\
\hline $4 \mathrm{H}-3,121$ & 29.71 & 1.40 & 18.82 & 0.027 & 0.15 & 1.12 & 0.16 & 7.0 \\
\hline $4 \mathrm{H}-4,122$ & 31.22 & 1.47 & 18.45 & 0.036 & 0.19 & 2.05 & 0.24 & 8.7 \\
\hline $4 \mathrm{H}-5,122$ & 32.72 & 1.54 & 17.64 & 0.025 & 0.14 & 1.25 & 0.16 & 7.8 \\
\hline $4 \mathrm{H}-6,120$ & 34.20 & 1.61 & 19.31 & 0.018 & 0.09 & 0.86 & 0.14 & 6.1 \\
\hline $4 \mathrm{H}-7,68$ & 35.18 & 1.65 & 18.56 & 0.032 & 0.17 & 1.60 & 0.18 & 8.9 \\
\hline $5 \mathrm{H}-1,121$ & 36.21 & 1.70 & 19.70 & 0.020 & 0.10 & 1.06 & 0.14 & 7.6 \\
\hline $5 \mathrm{H}-2,12 \mathrm{I}$ & 37.71 & 1.77 & 18.07 & 0.025 & 0.14 & 1.18 & 0.15 & 7.7 \\
\hline $5 \mathrm{H}-3,121$ & 39.21 & 1.84 & 17.29 & 0.014 & 0.08 & 0.69 & 0.12 & 5.6 \\
\hline $5 \mathrm{H}-4,12 \mathrm{I}$ & 40.71 & 1.90 & 28.71 & 0.017 & 0.06 & 0.75 & 0.12 & 6.3 \\
\hline $5 \mathrm{H}-5,12 \mathrm{I}$ & 42.21 & 1.95 & 28.39 & 0.028 & 0.10 & 1.00 & 0.14 & 7.1 \\
\hline $5 \mathrm{H}-6,121$ & 43.71 & 2.00 & 27.09 & 0.054 & 0.20 & 1.86 & 0.22 & 8.4 \\
\hline $6 \mathrm{H}-1,121$ & 45.71 & 2.06 & 32.52 & 0.088 & 0.27 & 2.68 & 0.29 & 9.2 \\
\hline $6 \mathrm{H}-3,121$ & 48.71 & 2.15 & 28.28 & 0.043 & 0.15 & 1.26 & 0.16 & 7.8 \\
\hline $6 \mathrm{H}-4,121$ & 50.16 & 2.19 & 29.24 & 0.043 & 0.15 & 1.42 & 0.18 & 7.9 \\
\hline $6 \mathrm{H}-5,121$ & 51.71 & 2.24 & 30.34 & 0.067 & 0.22 & 2.52 & 0.24 & 10.5 \\
\hline $6 \mathrm{H}-6,121$ & 53.21 & 2.29 & 31.19 & 0.045 & 0.15 & 1.72 & 0.26 & 6.6 \\
\hline $7 \mathrm{H}-5,121$ & 61.21 & 2.53 & 31.60 & 0.044 & 0.14 & 1.67 & 0.20 & . \\
\hline
\end{tabular}


Appendix (continued).

\begin{tabular}{|c|c|c|c|c|c|c|c|c|}
\hline \multirow[b]{2}{*}{$\begin{array}{l}\text { Core, section, } \\
\text { interval }(\mathrm{cm})\end{array}$} & \multirow[b]{2}{*}{$\begin{array}{l}\text { Depth } \\
\text { (mbsf) }\end{array}$} & \multirow[b]{2}{*}{$\begin{array}{l}\text { Age } \\
(\mathrm{Ma})\end{array}$} & \multirow[b]{2}{*}{$\begin{array}{c}\text { Bulk } \\
\text { accumulation rate } \\
\left(\mathrm{g} / \mathrm{m}^{2} / \mathrm{yr}\right)\end{array}$} & \multirow[b]{2}{*}{$\begin{array}{c}\text { TOC } \\
\text { accumulation rate } \\
\left(\mathrm{g} / \mathrm{m}^{2} / \mathrm{yr}\right)\end{array}$} & \multirow[b]{2}{*}{$\begin{array}{l}\text { TOC } \\
(\%)\end{array}$} & \multicolumn{3}{|c|}{ Carbonate-free residue } \\
\hline & & & & & & $\begin{array}{l}\text { TOC' }^{\prime} \\
(\%)\end{array}$ & $\begin{array}{r}\mathrm{N}^{\prime} \\
(\%)\end{array}$ & $\mathrm{TOC}^{\prime} / \mathrm{N}^{\prime}$ \\
\hline $8 \mathrm{H}-5,121$ & 70.71 & 2.82 & 28.88 & 0.053 & 0.18 & 2.14 & 0.24 & 8.9 \\
\hline $9 \mathrm{H}-5,120$ & 80.20 & 3.11 & 30.64 & 0.064 & 0.21 & 2.71 & 0.30 & 9.0 \\
\hline $10 \mathrm{H}-5,121$ & 89.71 & 3.40 & 28.35 & 0.031 & 0.11 & 1.46 & 0.16 & 9.1 \\
\hline $11 \mathrm{H}-5,121$ & 99.21 & 3.65 & 44.46 & 0.062 & 0.14 & 1.33 & 0.17 & 7.8 \\
\hline $12 \mathrm{H}-5,121$ & 108.71 & 3.85 & 45.31 & 0.063 & 0.14 & 1.70 & 0.17 & 10.0 \\
\hline $13 \mathrm{H}-5,120$ & 118.20 & 4.06 & 43.34 & 0.035 & 0.08 & 1.08 & 0.14 & 7.7 \\
\hline $14 \mathrm{H}-5,121$ & 127.71 & 4.26 & 45.78 & 0.032 & 0.07 & 1.37 & 0.15 & 9.1 \\
\hline $15 \mathrm{H}-5,121$ & 137.21 & 4.47 & 48.32 & 0.029 & 0.06 & 1.17 & 0.15 & 7.8 \\
\hline $16 \mathrm{H}-5,121$ & 146.71 & 4.67 & 42.83 & 0.034 & 0.08 & 1.27 & 0.16 & 7.9 \\
\hline $17 \mathrm{H}-5,121$ & 156.21 & 4.87 & 43.48 & 0.022 & 0.05 & 0.98 & 0.12 & 8.2 \\
\hline $18 \mathrm{H}-5,120$ & 165.70 & 5.08 & 48.08 & 0.029 & 0.06 & 1.09 & 0.14 & 7.8 \\
\hline $19 \mathrm{H}-5,119$ & 175.19 & 5.28 & 46.06 & 0.048 & 0.11 & 1.67 & 0.16 & 10.4 \\
\hline $20 \mathrm{H}-5,120$ & 184.70 & 5.48 & 47.66 & 0.167 & 0.35 & 1.25 & 0.15 & 8.3 \\
\hline $21 \mathrm{H}-5,120$ & 194.20 & 5.69 & 46.49 & 0.088 & 0.19 & 2.08 & 0.22 & 9.5 \\
\hline $22 \mathrm{H}-5,120$ & 203.70 & 5.89 & 47.34 & 0.034 & 0.07 & 0.98 & 0.13 & 7.5 \\
\hline $23 \mathrm{H}-5,121$ & 213.21 & 6.10 & 48.42 & 0.058 & 0.12 & 1.66 & 0.16 & 10.4 \\
\hline $24 \mathrm{H}-5,12 \mathrm{I}$ & 222.71 & 6.30 & 48.88 & 0.073 & 0.15 & 2.29 & 0.23 & 10.0 \\
\hline $25 \mathrm{H}-5,121$ & 232.21 & 6.50 & 49.22 & 0.049 & 0.10 & 1.33 & 0.14 & 9.5 \\
\hline $26 \mathrm{H}-5,121$ & 241.71 & 6.71 & 48.00 & 0.024 & 0.05 & 0.72 & 0.10 & 7.2 \\
\hline $27 \mathrm{H}-5,121$ & 251.21 & 6.91 & 48.24 & 0.063 & 0.13 & 1.61 & 0.16 & 10.1 \\
\hline $28 \mathrm{H}-5,121$ & 260.71 & 7.12 & 48.80 & 0.054 & 0.11 & 1.51 & 0.14 & 10.8 \\
\hline $29 \mathrm{H}-5,121$ & 270.21 & 7.32 & 45.88 & 0.041 & 0.09 & 1.02 & 0.12 & 8.5 \\
\hline $31 \mathrm{H}-5,121$ & 289.21 & 7.73 & 50.82 & 0.020 & 0.04 & 0.50 & 0.05 & 10.0 \\
\hline $32 \mathrm{H}-5,121$ & 298.71 & 7.93 & 49.51 & 0.025 & 0.05 & 0.63 & 0.05 & 12.6 \\
\hline $33 \mathrm{H}-5,121$ & 308.21 & 8.13 & 48.85 & 0.024 & 0.05 & 0.48 & 0.04 & 12.0 \\
\hline $34 \mathrm{H}-5,121$ & 317.71 & 8.34 & 47.81 & 0.019 & 0.04 & 0.48 & 0.04 & 12.0 \\
\hline $35 X-5,121$ & 327.21 & 8.54 & 47.39 & 0.019 & 0.04 & 0.52 & 0.05 & 10.4 \\
\hline $36 X-5,122$ & 336.92 & 8.78 & 32.87 & 0.013 & 0.04 & 0.51 & 0.05 & 10.2 \\
\hline $37 X-5,122$ & 346.62 & 9.11 & 28.11 & 0.011 & 0.04 & 0.44 & 0.06 & 7.3 \\
\hline $39 X-5,121$ & 366.01 & 9.77 & 32.99 & 0.013 & 0.04 & 0.50 & 0.05 & 10.0 \\
\hline $40 X-5,111$ & 375.61 & 10.10 & 32.07 & 0.013 & 0.04 & 0.49 & 0.04 & 12.3 \\
\hline $41 X-5,90$ & 385.10 & 10.43 & 33.25 & 0.013 & 0.04 & 0.58 & 0.05 & 11.6 \\
\hline $42 X-5,125$ & 395.15 & 10.77 & 32.16 & 0.039 & 0.12 & 1.50 & 0.17 & 8.8 \\
\hline $43 X-5,123$ & 404.73 & 11.10 & 30.89 & 0.015 & 0.05 & 0.57 & 0.06 & 9.5 \\
\hline $44 X-5,123$ & 414.43 & 11.43 & 32.67 & 0.013 & 0.04 & 0.44 & 0.04 & 11.0 \\
\hline $45 X-5,122$ & 424.12 & 11.76 & 32.67 & 0.016 & 0.05 & 0.54 & 0.06 & 9.0 \\
\hline $46 X-5,123$ & 433.73 & 12.09 & 32.43 & 0.013 & 0.04 & 0.41 & 0.05 & 8.2 \\
\hline $48 X-5,122$ & 453.02 & 12.75 & 31.60 & 0.013 & 0.04 & 0.38 & 0.04 & 9.5 \\
\hline $49 X-5,121$ & 462.71 & 13.08 & 32.37 & 0.013 & 0.04 & 0.47 & 0.05 & 9.4 \\
\hline $50 X-5,121$ & 470.81 & 13.36 & 32.93 & 0.020 & 0.06 & 0.59 & 0.05 & 11.8 \\
\hline $51 X-5,121$ & 480.51 & 13.73 & 23.44 & 0.009 & 0.04 & 0.58 & 0.06 & 9.7 \\
\hline $55 X-5,121$ & 518.81 & 15.68 & 23.34 & 0.007 & 0.03 & 0.37 & 0.04 & 9.3 \\
\hline $57 \mathrm{X}-5,121$ & 538.11 & 16.67 & 23.64 & 0.010 & 0.04 & 0.39 & 0.04 & 9.8 \\
\hline $58 \mathrm{X}-5,122$ & 547.72 & 17.16 & 24.82 & 0.010 & 0.04 & 0.38 & 0.03 & 12.7 \\
\hline $59 X-5,121$ & 557.41 & 17.65 & 24.43 & 0.007 & 0.03 & 0.30 & 0.03 & 10.0 \\
\hline $60 X-5,57$ & 566.47 & 18.11 & 24.35 & 0.007 & 0.03 & 0.31 & 0.03 & 10.3 \\
\hline $61 X-5,121$ & 576.81 & 18.64 & 24.94 & 0.010 & 0.04 & 0.39 & 0.04 & 9.8 \\
\hline $62 X-5,121$ & 586.51 & 19.14 & 24.82 & 0.007 & 0.03 & 0.39 & 0.05 & 7.8 \\
\hline $63 X-5,121$ & 596.21 & 19.63 & 25.31 & 0.013 & 0.05 & 0.64 & 0.06 & 10.7 \\
\hline $65 X-5,121$ & 615.51 & 20.45 & 35.83 & 0.014 & 0.04 & 0.48 & 0.07 & 6.9 \\
\hline $66 \mathrm{X}-5,121$ & 625.11 & 20.81 & 34.76 & 0.013 & 0.04 & 0.48 & 0.06 & 8.0 \\
\hline $72 \mathrm{X}-1,121$ & 676.71 & 22.75 & 37.28 & 0.015 & 0.04 & 0.55 & 0.04 & 13.8 \\
\hline $73 X-5,121$ & 692.41 & 23.34 & 37.30 & 0.011 & 0.03 & 0.61 & 0.07 & 8.7 \\
\hline $75 X-5,122$ & 711.72 & 24.07 & 37.10 & 0.015 & 0.04 & 0.53 & 0.04 & 13.3 \\
\hline $78 \mathrm{X}-1,81$ & 734.21 & 24.92 & 39.05 & 0.031 & 0.08 & 0.78 & 0.04 & 19.5 \\
\hline $130-807 \mathrm{~A}-$ & & & & & & & & \\
\hline $1 \mathrm{H}-1,124$ & 1.24 & 0.08 & 12.21 & 0.021 & 0.17 & 1.05 & 0.17 & 6.2 \\
\hline IH- 2,124 & 2.74 & 0.18 & 10.99 & 0.015 & 0.13 & 1.02 & 0.18 & 5.8 \\
\hline $1 \mathrm{H}-3,124$ & 4.24 & 0.28 & 11.23 & 0.009 & 0.08 & 0.74 & 0.13 & 5.8 \\
\hline $1 \mathrm{H}-4,124$ & 5.74 & 0.38 & 13.04 & 0.008 & 0.06 & 0.61 & 0.13 & 4.8 \\
\hline $2 \mathrm{H}-1,123$ & 8.63 & 0.57 & 12.71 & 0.009 & 0.07 & 0.75 & 0.13 & 5.7 \\
\hline $2 \mathrm{H}-2,123$ & 10.13 & 0.67 & 12.13 & 0.009 & 0.07 & 0.71 & 0.13 & 5.6 \\
\hline $2 \mathrm{H}-3,123$ & 11.63 & 0.77 & 12.36 & 0.010 & 0.08 & 0.74 & 0.12 & 6.0 \\
\hline $2 \mathrm{H}-4,123$ & 13.13 & 0.87 & 12.94 & 0.008 & 0.06 & 0.52 & 0.10 & 5.3 \\
\hline $2 \mathrm{H}-5,123$ & 14.63 & 0.97 & 12.48 & 0.010 & 0.08 & 0.70 & 0.13 & 5.4 \\
\hline $3 \mathrm{H}-1,123$ & 18.13 & 1.21 & 12.81 & 0.005 & 0.04 & 0.40 & 0.09 & 4.4 \\
\hline $3 \mathrm{H}-2,123$ & 19.63 & 1.30 & 11.69 & 0.010 & 0.09 & 0.65 & 0.11 & 6.1 \\
\hline $3 \mathrm{H}-3,123$ & 21.13 & 1.40 & 13.13 & 0.011 & 0.09 & 0.71 & 0.12 & 6.0 \\
\hline $3 \mathrm{H}-5,123$ & 24.13 & 1.60 & 13.54 & 0.008 & 0.06 & 0.50 & 0.09 & 5.4 \\
\hline $3 \mathrm{H}-6,123$ & 25.63 & 1.70 & 12.62 & 0.006 & 0.05 & 0.44 & 0.09 & 4.9 \\
\hline $4 \mathrm{H}-1,123$ & 27.63 & 1.84 & 12.34 & 0.007 & 0.06 & 0.46 & 0.08 & 5.6 \\
\hline $4 \mathrm{H}-2,123$ & 29.13 & 1.94 & 13.09 & 0.008 & 0.06 & 0.51 & 0.08 & 6.1 \\
\hline $4 \mathrm{H}-3,123$ & 30.63 & 2.04 & 11.61 & 0.007 & 0.06 & 0.53 & 0.10 & 5.5 \\
\hline
\end{tabular}


Appendix (continued).

\begin{tabular}{|c|c|c|c|c|c|c|c|c|}
\hline \multirow[b]{2}{*}{$\begin{array}{l}\text { Core, section, } \\
\text { interval }(\mathrm{cm})\end{array}$} & \multirow[b]{2}{*}{$\begin{array}{l}\text { Depth } \\
\text { (mbsf) }\end{array}$} & \multirow[b]{2}{*}{$\begin{array}{l}\text { Age } \\
\text { (Ma) }\end{array}$} & \multirow[b]{2}{*}{$\begin{array}{c}\text { Bulk } \\
\text { accumulation rate } \\
\left(\mathrm{g} / \mathrm{m}^{2} / \mathrm{yr}\right)\end{array}$} & \multirow[b]{2}{*}{$\begin{array}{c}\text { TOC } \\
\text { accumulation rate } \\
\left(\mathrm{g} / \mathrm{m}^{2} / \mathrm{yr}\right)\end{array}$} & \multirow[b]{2}{*}{$\begin{array}{l}\text { TOC } \\
(\%)\end{array}$} & \multicolumn{3}{|c|}{ Carbonate-free residue } \\
\hline & & & & & & $\begin{array}{l}\mathrm{TOC}^{\prime} \\
(\%)\end{array}$ & $\begin{array}{l}\mathrm{N}^{\prime} \\
(\%)\end{array}$ & $\mathrm{TOC}^{\prime} / \mathrm{N}^{\prime}$ \\
\hline $4 \mathrm{H}-4,123$ & 32.13 & 2.10 & 25.54 & 0.013 & 0.05 & 0.36 & 0.08 & 4.8 \\
\hline $4 \mathrm{H}-5,123$ & 33.63 & 2.15 & 27.14 & 0.028 & 0.10 & 0.51 & 0.10 & 5.2 \\
\hline $4 \mathrm{H}-6,123$ & 35.13 & 2.19 & 26.75 & 0.011 & 0.04 & 0.55 & 0.09 & 6.1 \\
\hline $5 \mathrm{H}-1,123$ & 37.13 & 2.25 & 26.23 & 0.006 & 0.02 & 0.56 & 0.10 & 5.7 \\
\hline $5 \mathrm{H}-2,123$ & 38.63 & 2.30 & 27.77 & 0.020 & 0.07 & 0.63 & 0.09 & 6.8 \\
\hline $5 \mathrm{H}-3,123$ & 40.13 & 2.35 & 28.65 & 0.025 & 0.09 & 0.85 & 0.10 & 8.5 \\
\hline $5 \mathrm{H}-4,123$ & 41.63 & 2.39 & 27.77 & 0.047 & 0.17 & 1.85 & 0.22 & 8.4 \\
\hline $5 \mathrm{H}-5,123$ & 43.13 & 2.44 & 26.88 & 0.017 & 0.07 & 0.80 & 0.11 & 7.6 \\
\hline $5 \mathrm{H}-6,123$ & 44.63 & 2.49 & 25.70 & 0.012 & 0.05 & 0.42 & 0.07 & 6.4 \\
\hline $6 \mathrm{H}-1,124$ & 46.64 & 2.55 & 26.58 & 0.018 & 0.07 & 0.71 & 0.09 & 8.4 \\
\hline $6 \mathrm{H}-2,124$ & 48.14 & 2.59 & 26.58 & 0.017 & 0.06 & 0.55 & 0.08 & 6.7 \\
\hline $6 \mathrm{H}-3,124$ & 49.64 & 2.64 & 28.42 & 0.031 & 0.11 & 1.30 & 0.14 & 9.2 \\
\hline $11 \mathrm{H}-5,123$ & 100.10 & 4.20 & 27.93 & 0.014 & 0.05 & 0.58 & 0.10 & 6.1 \\
\hline $12 \mathrm{H}-5,123$ & 109.60 & 4.49 & 29.24 & 0.017 & 0.06 & 0.82 & 0.11 & 7.4 \\
\hline $13 \mathrm{H}-5,123$ & 119.10 & 4.78 & 30.15 & 0.016 & 0.05 & 0.61 & 0.09 & 6.5 \\
\hline $14 \mathrm{H}-5,123$ & 128.60 & 5.06 & 40.89 & 0.022 & 0.05 & 0.72 & 0.14 & 5.3 \\
\hline $15 \mathrm{H}-4,123$ & 135.40 & 5.21 & 38.63 & 0.029 & 0.08 & 0.92 & 0.12 & 7.8 \\
\hline $16 \mathrm{H}-5,123$ & 147.60 & 5.49 & 43.14 & 0.031 & 0.07 & 1.14 & 0.15 & 7.7 \\
\hline $17 \mathrm{H}-5,123$ & 157.10 & 5.71 & 44.77 & 0.023 & 0.05 & 0.84 & 0.18 & 4.6 \\
\hline $18 \mathrm{H}-5,123$ & 166.60 & 5.93 & 42.65 & 0.031 & 0.07 & 1.20 & 0.19 & 6.3 \\
\hline $19 \mathrm{H}-5,123$ & 176.10 & 6.14 & 43.22 & 0.043 & 0.10 & 1.25 & 0.18 & 7.1 \\
\hline $20 \mathrm{H}-5,123$ & 185.60 & 6.36 & 46.36 & 0.025 & 0.05 & 0.94 & 0.11 & 8.3 \\
\hline $21 \mathrm{H}-5,123$ & 195.10 & 6.58 & 43.49 & 0.016 & 0.04 & 0.62 & 0.10 & 6.1 \\
\hline $22 \mathrm{H}-5,123$ & 204.60 & 6.79 & 46.18 & 0.023 & 0.05 & 0.66 & 0.12 & 5.4 \\
\hline $23 \mathrm{H}-5,123$ & 214.10 & 7.01 & 49.01 & 0.019 & 0.04 & 0.61 & 0.11 & 5.7 \\
\hline $24 \mathrm{H}-5,123$ & 223.60 & 7.23 & 43.95 & 0.019 & 0.04 & 0.69 & 0.10 & 7.2 \\
\hline $25 \mathrm{H}-5,123$ & 233.10 & 7.44 & 43.50 & 0.017 & 0.04 & 0.43 & 0.07 & 6.2 \\
\hline $26 \mathrm{H}-5,123$ & 242.60 & 7.66 & 42.26 & 0.020 & 0.05 & 0.58 & 0.09 & 6.8 \\
\hline $27 \mathrm{H}-5,123$ & 252.10 & 7.88 & 43.58 & 0.017 & 0.04 & 0.41 & 0.08 & 5.0 \\
\hline $28 \mathrm{H}-5,123$ & 261.60 & 8.10 & 41.52 & 0.014 & 0.04 & 0.39 & 0.09 & 4.2 \\
\hline $29 X-5,123$ & 271.30 & 8.32 & 45.44 & 0.016 & 0.04 & 0.43 & 0.08 & 5.4 \\
\hline $30 X-5,123$ & 281.00 & 8.54 & 41.86 & 0.019 & 0.05 & 0.53 & 0.11 & 5.0 \\
\hline $31 X-5,123$ & 290.70 & 8.85 & 17.22 & 0.006 & 0.03 & 0.36 & 0.11 & 3.2 \\
\hline $32 X-5,123$ & 299.90 & 9.37 & 19.19 & 0.009 & 0.05 & 0.47 & 0.13 & 3.6 \\
\hline $33 X-5,123$ & 309.50 & 9.91 & 19.30 & 0.007 & 0.04 & 0.41 & 0.09 & 4.7 \\
\hline $34 X-5,123$ & 319.20 & 10.46 & 20.87 & 0.008 & 0.04 & 0.40 & 0.10 & 4.2 \\
\hline $35 X-5,123$ & 328.40 & 10.98 & 18.71 & 0.007 & 0.04 & 0.37 & 0.10 & 3.9 \\
\hline $36 X-5,123$ & 338.10 & 11.53 & 19.87 & 0.006 & 0.03 & 0.33 & 0.12 & 2.8 \\
\hline $37 X-5,123$ & 347.80 & 12.08 & 19.57 & 0.008 & 0.04 & 0.46 & 0.06 & 7.7 \\
\hline $38 X-5,123$ & 357.40 & 12.63 & 18.16 & 0.006 & 0.03 & 0.38 & 0.10 & 4.0 \\
\hline $39 X-5,123$ & 367.10 & 13.18 & 18.48 & 0.007 & 0.04 & 0.34 & 0.09 & 4.0 \\
\hline $40 X-5,126$ & 377.00 & 13.74 & 18.41 & 0.004 & 0.02 & 0.35 & 0.07 & 5.0 \\
\hline $42 X-5,123$ & 396.40 & 14.92 & 20.02 & 0.005 & 0.03 & 0.37 & 0.11 & 3.4 \\
\hline $44 X-5,109$ & 415.70 & 16.09 & 21.72 & 0.006 & 0.03 & 0.48 & 0.08 & 6.3 \\
\hline $46 X-5,131$ & 435.10 & 17.27 & 21.96 & 0.005 & 0.02 & 0.36 & 0.11 & 3.4 \\
\hline $48 X-5,123$ & 454.30 & 18.43 & 21.34 & 0.004 & 0.02 & 0.22 & 0.09 & 2.6 \\
\hline $50 X-5,123$ & 473.60 & 19.60 & 20.94 & 0.003 & 0.02 & 0.41 & 0.07 & 5.8 \\
\hline $52 X-5,123$ & 493.00 & 20.77 & 19.91 & 0.005 & 0.02 & 0.92 & 0.10 & 9.2 \\
\hline $54 X-5,123$ & 512.30 & 21.88 & 34.63 & 0.014 & 0.04 & 0.98 & 0.10 & 10.0 \\
\hline $56 X-5,124$ & 531.20 & 22.51 & 39.73 & 0.012 & 0.03 & 1.04 & 0.09 & 11.6 \\
\hline $58 X-5,123$ & 550.60 & 23.15 & 37.30 & 0.007 & 0.02 & 0.66 & 0.09 & 7.1 \\
\hline
\end{tabular}

Notes: The appendix table also lists the total organic carbon content of the bulk sediment (TOC), the organic carbon and nitrogen contents of the carbonate-free residue (TOC' and N), and the TOC' $/ \mathrm{N}^{\prime}$ ratios of Leg 130 sites. The ages of the samples are based on mean sedimentation rates (Kroenke, Berger, Janecek, et al., 1991). 